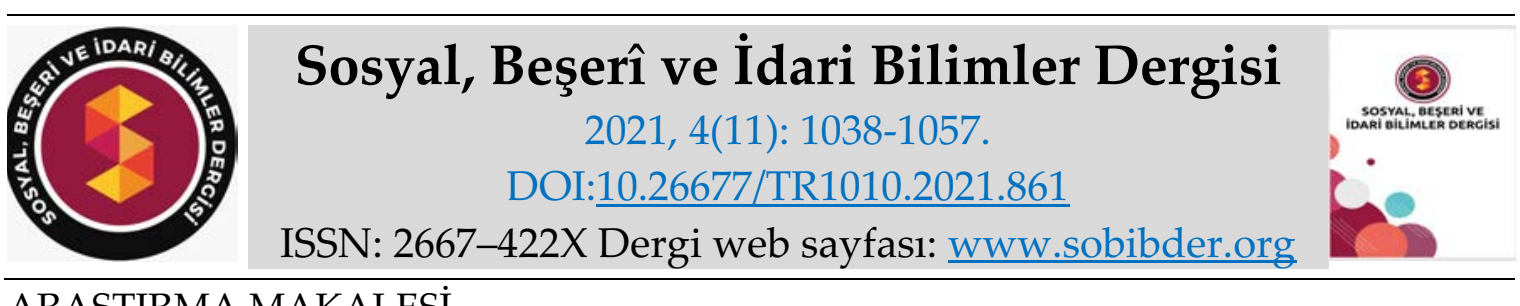

ARASTTIRMA MAKALESI

\title{
Kasrik Boğazı ve Cizre Arasında Kalan Alanın Jeomorfolojisi*
}

Prof. Dr. Ali Fuat DOĞU, Yüzüncü Yıl Üniversitesi, Edebiyat Fakültesi, Van, e-posta: alifuatdogu@gmail.com

ORCID: https://orcid.org/0000-0002-6104-3915

Evin EK SEVGİ, Kumçatı Anadolu İmam Hatip Lisesi, Şırnak, e-posta: helbestevin21@gmail.com ORCID: https://orcid.org/0000-0002-1083-1225

Öz

Güneydoğu Anadolu Bölgesi'nde, Şırnak iline bağlı Cizre ve yakın çevresine kurulmuş Dicle Nehri ve kollarını (Kızılsu Çayı) kapsayan bu çalışmanın amacı, Kasrik Boğazı'nı yararak bölgeye yerleşen Kızılsu Çayı'nın vadi gelişim sürecini, jeomorfolojik özelliklerini, alandaki tektonik hareketlere tepkisini ve bölgenin morfolojik yapısına etki eden faktörleri ele almaktır. Alan, Türkiye'nin önemli akarsularından Dicle Nehri vadisinin bir bölümünü kapsaması ve tektonizma-flüvyal sistem ilişkisi açısından önemlidir. Araştırmada Kasrik Boğazı çevresinde; boğazın (antesedant yarma vadi) oluşum süreci, tektonizmanın morfolojiye etkisiyle oluşmuş dik yapılar ve kaya taraçaları ele alınmış ve tektonizma-flüvyal sistem ilişkisi işlenmiştir. Cizre ilçe merkezinin kurulduğu alan ve yakın çevresi ise Dicle Nehri taraçalarıyla dikkat çekmektedir. Çalışma alanında Dicle Nehri S1 (100-125 m), S2 (50-70 m), S3 (10-30) ve S4 (3-5 m) sekilerini oluşturmuştur. Bu sekilerden en üstteki (S1) seviye bazaltlarla örtülmüş ve yapısal lav platosu oluşmuştur. Bunun yanında çalışma alanı içinde Dicle Nehri ve kollarının sergilediği farklı drenaj ağları da mevcuttur.

* Bu makale "Kasrik Boğazı ve Cizre Arasında Kalan Alanın Fiziki Coğrafyası" adlı Yüksek Lisans tezinden elde edilmiştir.

Anahtar Kelimeler: Dicle Nehri, Kasrik Boğazı, Akarsu Sekisi, Antesedant Yarma Vadi.

Makale Gönderme Tarihi: 26.07.2021

Makale Kabul Tarihi: 01.11.2021

\section{Önerilen Atıf:}

Doğu, A. F. ve Ek Sevgi, E. (2021). Kasrik Boğazı ve Cizre Arasında Kalan Alanın Jeomorfolojisi, Sosyal, Beşeri ve İdari Bilimler Dergisi, 4(11): 1038-1057. 


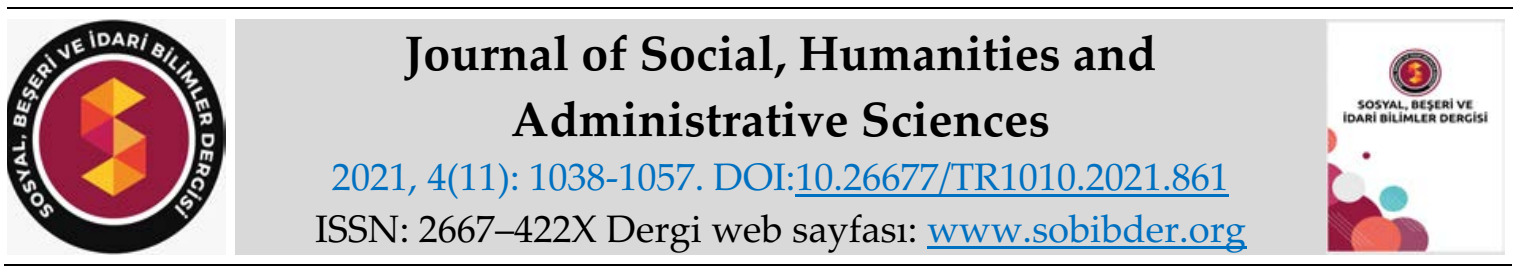

RESEARCH PAPER

\title{
Geomorphology of the Area Between Kasrik George and Cizre
}

Prof. Dr. Ali Fuat DOĞU, Yüzüncü Yıl University, Faculty of Letters, Van, e-mail: alifuatdogu@gmail.com

ORCID: https://orcid.org/0000-0002-6104-3915

Evin EK SEVGİ, Kumçatı Anatolian Imam Hatip High School, Şırnak, e-mail: helbestevin21@gmail.com

ORCID: https://orcid.org/0000-0002-1083-1225

\begin{abstract}
The aim of this study, which covers the Tigris River and its tributaries (Kizılsu River) established in Cizre and its surroundings, in the province of Şırnak in the Southeastern Anatolia Region, it is to examine the valley evolution process, geomorphologicalfeatures, response to tectonic. This works the evolution process of the Kizılsu River, which settled in the region by crossing Kasrik George the aim of to the factors affecting the morphological structure of the region. This area is important in terms of covering a part of Tigris River valley, one of Turkey's most important rivers and tectonism-fluvial system relationship. In this research around Kasrik George; the formation process of the George (antesedant split valley), the step structure sandrock terrace formed by effect of tectonism on morphology are discussed and tectonism-fluvial system relationship is studied. The area where the Cizre district center was established and its immediate surroundings draw attention with the terraces of the Tigris River. In this study area, the Tigris River formed S1 (100-125 m), S2 (50-70 m), S3 (10-30 m) and S4 (3-5 m) terraces. The upper (S1) level of these landforms is covered with basalt sand formed a structural lava plateau. In addition, different drainage networks formed by the Tigris River and its tributaries are also seen in the study area.
\end{abstract}

Keywords: Tigris River, Kasrik George, Stream Terrace, Andesedant Split Valley.

Received: 26.07 .2021

Accepted: 01.11.2021

\section{Suggested Citation:}

Doğu, A. F. and Ek Sevgi, E. (2021). Geomorphology of the Area Between Kasrik George and

Cizre, Journal of Social, Humanities and Administrative Sciences, 4(11): 1038-1057. 


\section{Gíriş}

Anadolu levhası ile Arap platformunun "kontakt" noktasına yakın olan çalışma alanı, tektonik oluşumlar bakımından çeşitlilik göstermekte ve önemli bir tektonik etkileşim kuşağında bulunmaktadır. Bölgede Jura tipi kıvrımlı yapılar kuzey-güney yönlü sıkışma hareketlerine bağlı olarak oluşmuştur. Bu kıvrımlı yapıların zamanla dirençlerinin kırılması ile faylanmalar ve sonrasında ise bindirme ve şaryajlar şeklinde farklı morfolojik yapılar oluşmuştur (Yıldırım ve Karadoğan, 2005; Özgen, Tonbul ve Karadoğan, 2005).

Bölgedeki jeomorfolojik gelişim, Tersiyer'den günümüze kadar geçen süre içerisindeki tektonik hareketler ile flüviyal süreçlerin birlikte işlemeleri sonucunda meydana gelmiştir. Ancak bu durumun ortaya çıkmasında, Arap plakasının Anadolu'yu sıkıştırması etkili olmuşken (ÜstMiyosen Pliyosen) dalan levhalar Doğu ve Güneydoğu Anadolu'nun bölgesel yükselimine neden olmuş ve volkanik aktiviteleri de tetiklemiştir (Siler ve Şengün, 2016). Bölgede, Pleyistosen başlarında meydana gelen bölgesel yükselme ve yüzey volkanizması faaliyetleri sahanın jeomorfolojik gelişiminde önemli olayların meydana gelmesini sağlamıştır (Siler ve Şengün, 2016). Yine Siler ve Şengün 'ün (2016) belirttiği gibi Pleyistosen çıkışlı Alem Dağı akışkan bazaltları Cizre ve Suriye sınırına kadar etkili olmuştur. Söz konusu volkanik oluşum bölge jeomorfolojisinde önemli bir yere sahiptir.

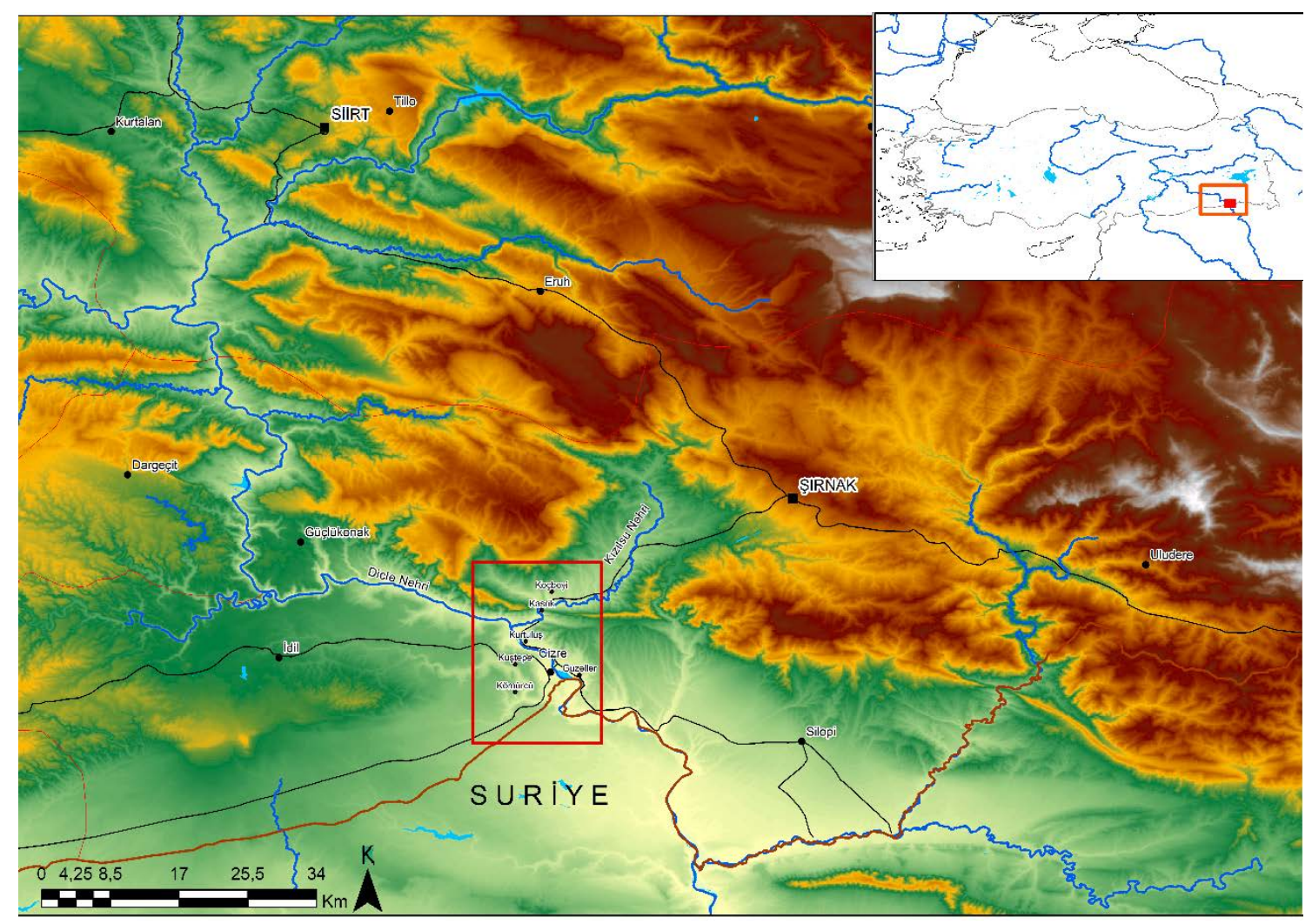

Harita 1. Araştırma Alanının Lokasyon Haritası

Araştırma alanı Şırnak ilinin güneybatısında yer alan Cizre ve yakın çevresini kapsamaktadır. Sahanın sınırları tespit edilirken bazı yerleşim alanları, jeolojik ve jeomorfolojik özellikler göz önünde bulundurulmuştur. Çalışma alanı karstik saha bakımından zengin olan Cudi Dağı ve Kuvaterner yaşlı akarsu çökelleri ve volkanik kayaçları bakımından zengin olan bir alan içerisinde bulunmaktadır. Saha kuzeyde Kasrik Boğazını içine alacak şekilde, güneyde ise Türkiye-Suriye siyasi sınırına dayanacak şekilde belirlenmiştir. Doğuda ve Batıda belirgin bir doğal sınır olmamakla birlikte Dicle Nehri taraçaları ve yapısal platolar esas alınmıştır (Harita 1). 
Bu çalışmadaki amaç Kasrik Boğazı ve Cizre arasında kalan alanın jeomorfolojik özelliklerini araştırmak, Dicle ve Kızılsu Nehirlerinin vadi gelişim süreçlerini açıklamak, Kasrik Boğazının oluşumunu, akarsu sekilerini, volkanik, tektonik ve flüvyal süreçlerin birbirleriyle ilişkisini ortaya koymaktır.

\section{METOT ve MATERYAL}

İnceleme alanındaki çalışma, fiziki coğrafya araştırma yöntem ve tekniklerine göre; ön hazırlık (büro çalışmaları), arazi çalışmaları (gözlem, ölçme, örneklem, resimleme), istatiksel ve sayısal verilerin hazırlanması ve haritaların oluşturulması aşamaları göz önünde bulundurularak gerçekleştirilmiştir.

Ön hazırlık (büro çalışmaları) aşamasında, sahaya ve konuya yönelik literatür taraması oluşturulmuş, elde bulunan ve ulaşılması gereken ilgili çalışmalar temin edilip arşivlenmiştir. Cizre (Şırnak) ve yakın çevresi arasındaki saha ile ilgili çalışmalar başta olmak üzere, komşu alanlar veya benzer konularla ilgili, başta coğrafya alanında yapılan çalışmalar, tezler, raporlar, makaleler, bültenler ve istatistiki bilgiler toplanmıştır. Harita genel komutanlığına ait 1/100000 ölçekli topografya haritasından (Cizre N48 Paftası) ve 1/25000'lik (N48a2, N48a3 paftası) paftalardan faydalanılmıştır. Jeolojik özelliklerin açılanmasında Maden Tetkik ve Arama Genel Müdürlüğünden, Cizre ilçesi için hazırlamış olduğu 2007 yılına ait 1/100000'lik jeoloji haritasından ve etüt raporlarından faydalanılmıştır. İklim özelliklerinin incelenmesinde Devlet Meteoroloji İşleri Genel Müdürlüğü'ne ait Cizre'deki istasyondan Cizre ilçesi için hazırlanmış iklim verileri kullanılmıştır.

Tüm bu çalışmalardan sonra elde edilen bütün bilgi ve belgeler ile arazi gözlemleri sırasında taslak haritalar üzerinde yapılan işaretlenmelerin değerlendirilmesi sonucunda asıl haritalar oluşturulmuştur. En doğru sonuçlara ulaşılması için elde edilen veriler eldeki sayısal topografya haritalarının üzerine bilgisayar ortamına aktarılması sağlanmış ve böylece sorgulamaların yapılabildiği bir konuma getirilmiştir. Araştırmada kullanılan haritaların çiziminde CBS programları (Mapinfo ve Arcgis) ve Photoshop programı kullanılmıştır.

\section{BULGULAR}

\section{İnceleme Alanının Jeolojik Özellikleri}

Güneydoğu Anadolu Bölgesinde, yerel kaya birimlerini temsil eden Güneydoğu Anadolu otoktonu aynı zamanda Arap platformunun kuzeydeki uzantısıdır. Güneydoğu Anadolu otoktonu, Prekambriyen-Kuvaterner yaşlı genelde platform tipi çökellerden oluşur (MTA, 2007).

Jeolojik açıdan zengin bir saha olan araştırma alanının en yaşlı birimi, Orta Maastrihtiyen yaşlı Üçkiraz formasyonudur. Killi kireçtaşlarından oluşan formasyon, açı veya derin deniz ortamında çökelmiştir. Üçkiraz formasyonu üzerinde yer alan Germav formasyonu (kumtaşı, marn, şeyl vb.) da derin deniz-denizaltı yamacı ya da yamaç öneyi gibi alanlarda birikmiştir. (MTA, 2007). Çoğunlukla Eosen yaşlı kabul edilen ve Üst Kretase yaşlı birimlerin üstünü diskordant olarak örten Midyat formasyonu ya da Midyat kalkerleri de denizel fasiyeste oluşmuşlardır. Bu da vaktinde deniz olan şimdi kara halinde bulunan adı geçen sahanın bir transgresyona sahne olduğu ve bugünkü görünümünü aldığını doğrulamaktadır (Biricik, 1975; MTA, 2007). Midyat formasyonu birimlerini uyumsuz bir şekilde örten birim Üst MiyosenPliyosen yaşı olarak kabul edilen Şelmo formasyonudur (çakıltaşı, kumtaşı, silttaşı vb.). Önce gölsel daha sonra karasal fasiyes koşullarını yansıtan bu formasyon Alem Dağı (İdil) bazaltları ile Lahta formasyonu tarafından örtülmüştür. (Karadoğan ve Coşkun, 2018; Sunkar ve Karataş, 
2014; Karadoğan ve Kozbe, 2013; Karadoğan, 2018; MTA, 2007). Pliyo-Kuvaterner birimi olan Lahta formasyonu (konglomera, silttaşı ve çamurtaşları) Cizre doğusunda geniş yer kaplar ve Şelmo formasyonuyla basit bir diskordans oluşturur (Yıldırım ve Karadoğan, 2010; MTA, 2007). Sahadaki Kuvaterner birimleri ise bazaltlar, eski ve yeni alüvyonlardan oluşmaktadır. Cizre batısında geniş alanlar kaplayan bu bazaltlar, Siler ve Şengün'e (2016) göre Alem Dağından çıkmıştır. Çalışma alanında geniş bir alan kaplayan eski alüvyonlar (gevşek tutturulmuş konglomera, kumtaşı, silttaşı ve çamurtaşları) Kuvaterner (Pleyistosen) döneminde yaşanan buzul ve buzularası dönemin kalıntılarıdır. Dicle Nehrinin buzul döneminde aşındırıp buzularası dönemde biriktirmesiyle bu birimler üstünde seki sistemleri gelişmiştir. Genç Kuvaterner (Holosen)'e ait yeni alüvyonlar, Dicle Nehri ve yan kollarının yataklarında çakıl, kum, kil ve siltten oluşan alçak sekileri ve vadi tabanlarının malzemesini meydana getiren alüvyonlardır (Karadoğan ve Kozbe, 2013). Çalışma alanındaki en güncel birimleri bu yeni alüvyonlar oluşturmaktadır.

Çalışma alanı Güneydoğu Toros Dağlarının kenar kıvrımları kuşağının güney kesimi üzerinde bulunmaktadır. Bölgenin bugünkü yer şekillerinin oluşumu ve tektonik gelişimi Paleotektonik süreçlerden çok Neotektoniğin etkisinde gelişmiştir. Neotektonik, Miyosen ortalarında Arabistan, Avrasya levhalarının çarpışması sonucu, Anadolu levhasının batıya doğru hareket etmesi bölgenin Orta Miyosen sonlarında doğu-batı yönlü sıkışma etkisinde kalarak yükselmesine ve faylanma, bindirme sistemlerinin gelişmesine yol açmıştır (Güneysu, 1989). Paleozoik-Mesozoyik döneminde zaman zaman duraysız platform niteliğinde olan bölgede Üst Kampaniyen-Alt Maastrihtiyen'de Arap plakası ile Anadolu-Torid platformu arasından kaynaklanan Koçali-Karadut naplarının yerleşmesine ev sahipliği yapmıştır. Miyosen'de Anadolu-Torid platformundan ve Neotetisin kuzey kolundan kaynaklanan Bitlis-PötürgeMalatya naplarının Güneydoğu Anadolu Bölgesi üzerine yerleşimine bağlı olarak bölge etkilenerek kıvrılmış, kırılmış ve kendi içinde ekaylanmıştır (MTA, 2007).

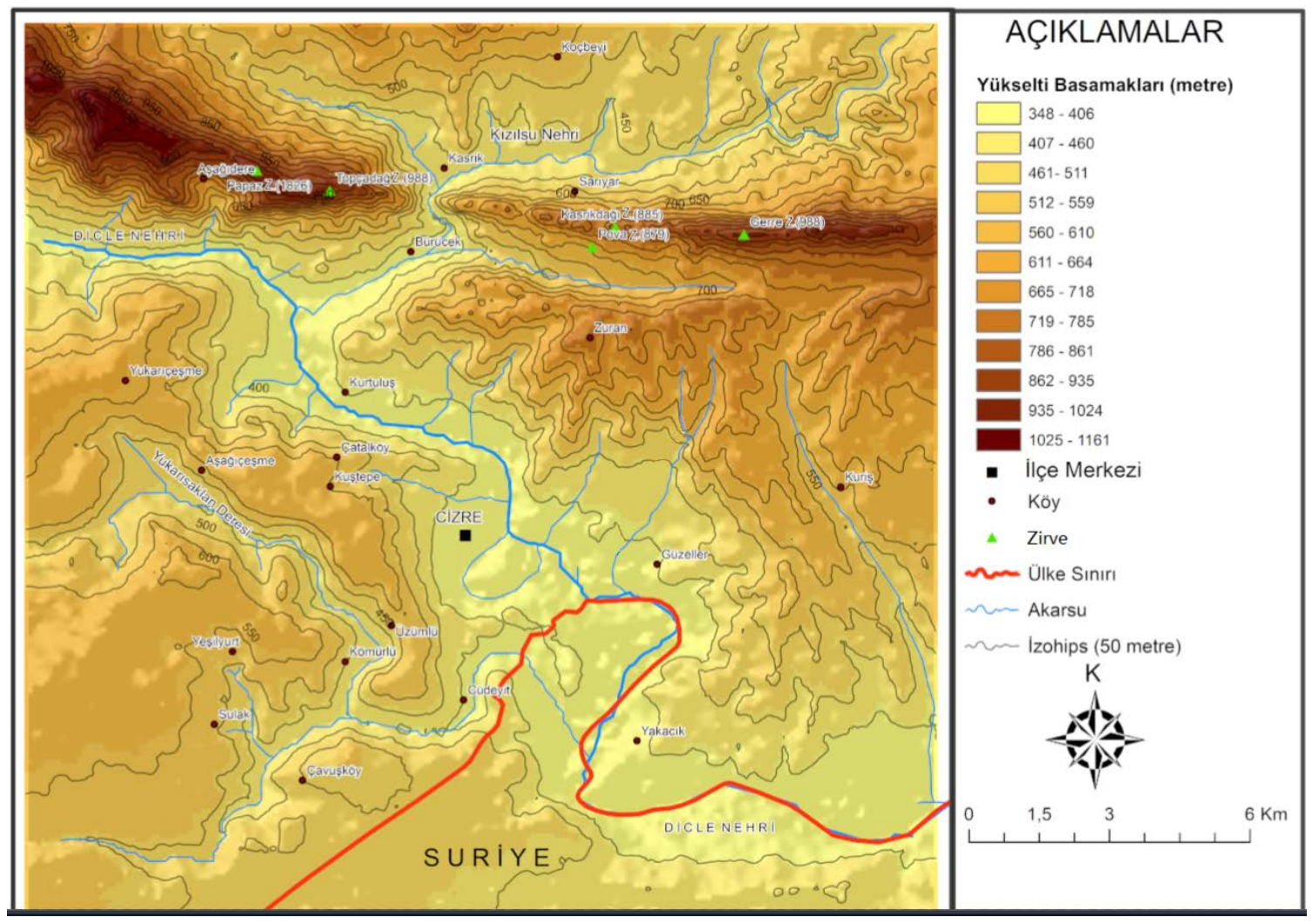

Harita 2: Çalışma Alanının Topoğrafya Haritası 
Güneydoğu Anadolu Bölgesi, genellikle geniş bir plato görünümünde olup hafifçe kıvrımlı ve kısmen de faylı bir jeolojik yapıya sahiptir (Sözer, 1984) (Harita 2). Çalışma alanı çevresinde de irili ufaklı çok sayıda ve farklı türde faylar bulunmaktadır. Bunların en büyüğü ve önemlisi çalışma alanının kuzeyinde bulunan Doğu-Batı yönünde uzanış gösteren bindirme fayıdır. Birbirine paralel uzanış gösteren iki fayın daha kuzeyde kalanı bindirme fayı iken güneydeki düşey atımlı normal faydır. Düşey atımlı normal fay Dicle Nehri'nin doğusunda bindirme fayı ile birleşmektedir (Harita 3).

Sonuç olarak Kasrik Boğazı ve Cizre arasında kalan alanın jeomorfolojisinin şekillenmesinde şüphesiz yapısal ve tektonik özellikler çok etkili olmuştur. Dicle Nehri batısında uzanan bazaltlar bu kesimde aşınmaya karşı direnç göstererek kornişler oluşturmuştur. Kasrik Boğazı çevresinde Midyat formasyonu birimleri üzerinde de sıkışma hareketi ve tektonizmanın morfolojiye etkisiyle dik yapılar (kret) oluşmuştur.

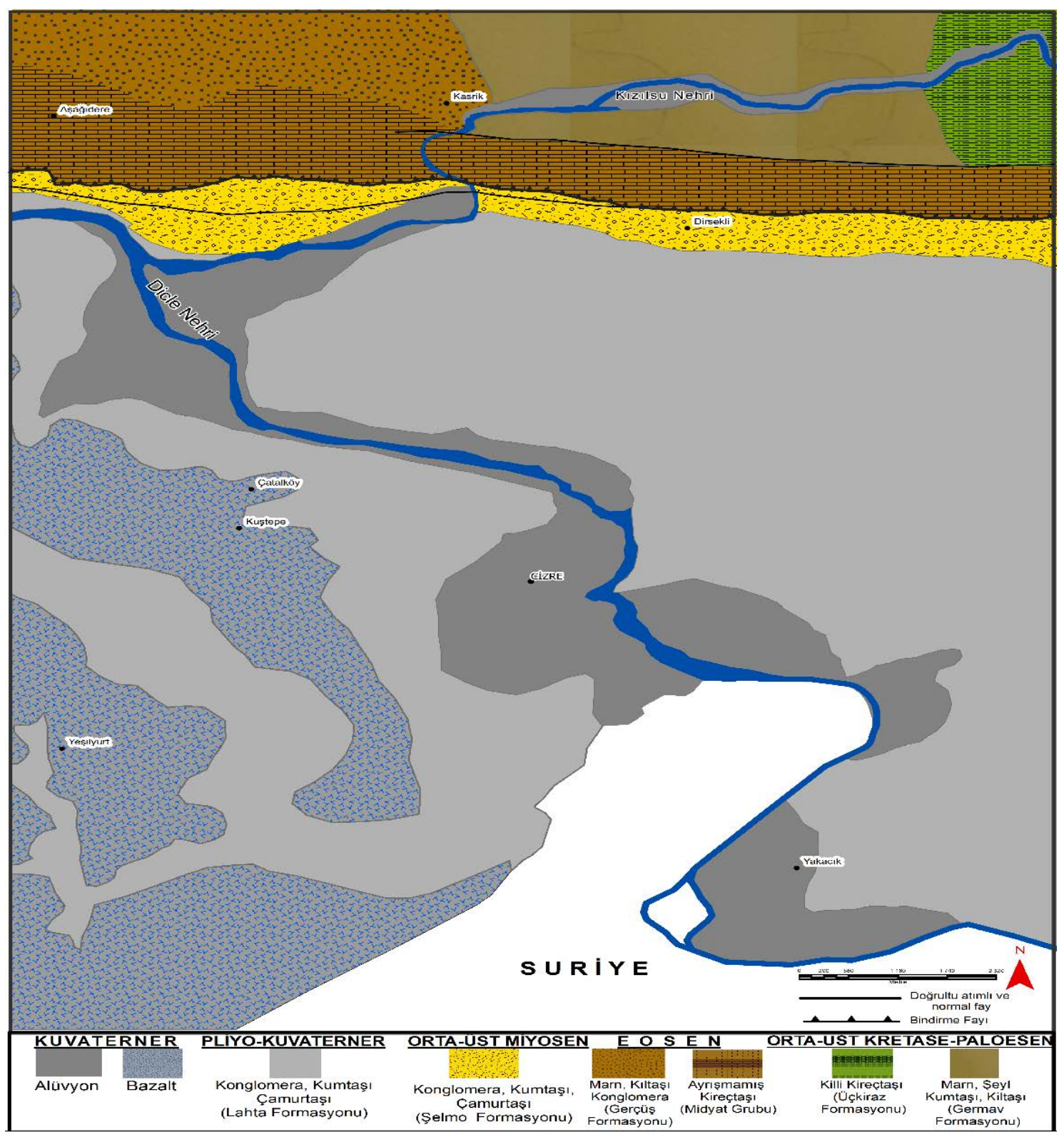

Harita 3. Çalışma Alanının Jeoloji Haritası

Kaynak: Maden Tetkik ve Arama Genel Müdürlüğü, 2007. 


\section{İnceleme Alanının Hidrografya Özellikleri}

Şırnak ili 2019 yılı çevre durum raporuna göre, Şırnak ve yakın çevresi Dicle Havzası içinde sayılmaktadır. Şırnak'taki bütün akarsular Dicle'nin kollarını oluşturur (Coşkun, Ayman, Yumruk ve Aşkar, 2019). Çalışma alanına etkide bulanan ve incelenen önemli akarsular ise Dicle Nehri ve Kızılsu Çayı'dır.

Dicle Nehri havzası başlangıç alanı Elazığ ili sınırlarındaki Hazar Gölü'nün güneyinden doğan Maden Çayı ile Eğil ilçesinin doğusundan gelen Dipni Çayı'nın birleştiği yerdir. Aynı yönde akışına devam etmeden önce Diyarbakır'ın 22 km kuzeyinde Devegeçidi Çayı'nı da alır. Diyarbakır'ı geçtikten sonra doğuya doğru yönelen Dicle Nehri derin ve geniş bir yatak içinde akış göstermektedir. Bu akış esnasında birçok önemli kolu toplayarak Cizre sınırına ulaşır ve buradan Türkiye topraklarını terk eder. Maden Çayı üzerinde ilk kaynağının rakımı $1.155 \mathrm{~m}$ iken, Diyarbakır önlerinde 560 m, Cizre'de ise 360 m’ye düşer (Bedirhanoğlu Yıldız, 2013). Çalışma alanında 360-370 m yükseltiden akan Dicle Nehri ve kolları bölgenin şekillenmesinde son derece önemli bir role sahiptir.

Nehrin sularının \%45'lik bölümü Türkiye'den beslenmektedir (Ergün ve Gürbüz, 2012; Zeybek, Ahıska ve Yıldız, 2016). Dicle Nehri geçtiği yerlerde sulama, içme suyu sağlama, balıkçılık gibi birçok alanda kullanılmaktadır. Dicle Nehrinin Türkiye sınırları içerisindeki su potansiyeli 21×109 $\mathrm{m}^{3^{\prime}}$ tür ve bu Türkiye su potansiyelinin \%11'i demektir (Bedirhanoğlu Yıldız, 2013).

Su potansiyeli yüksek olan nehrin taşıdığı su miktarı aylara ve mevsimlere göre değişiklik göstermektedir. Türkiye'nin karasal bölgelerinde ilkbahar ve yaz başlarının yağışlı geçmesinden dolayı yükselen akım, yaz kuraklığının başlamasıyla düşer. Akdeniz iklim bölgesinde ise kışın yağışlı geçmesine bağlı olarak yükselen akım, yazın yağışın azalmasından dolayı asgari seviyesine iner (Atalay, 2016; 185-186). Akımın düşük olduğu dönemlerde nehir içinde kum adaları oluşurken akımın yükselmesiyle bu adalar sular altında kalmaktadır.

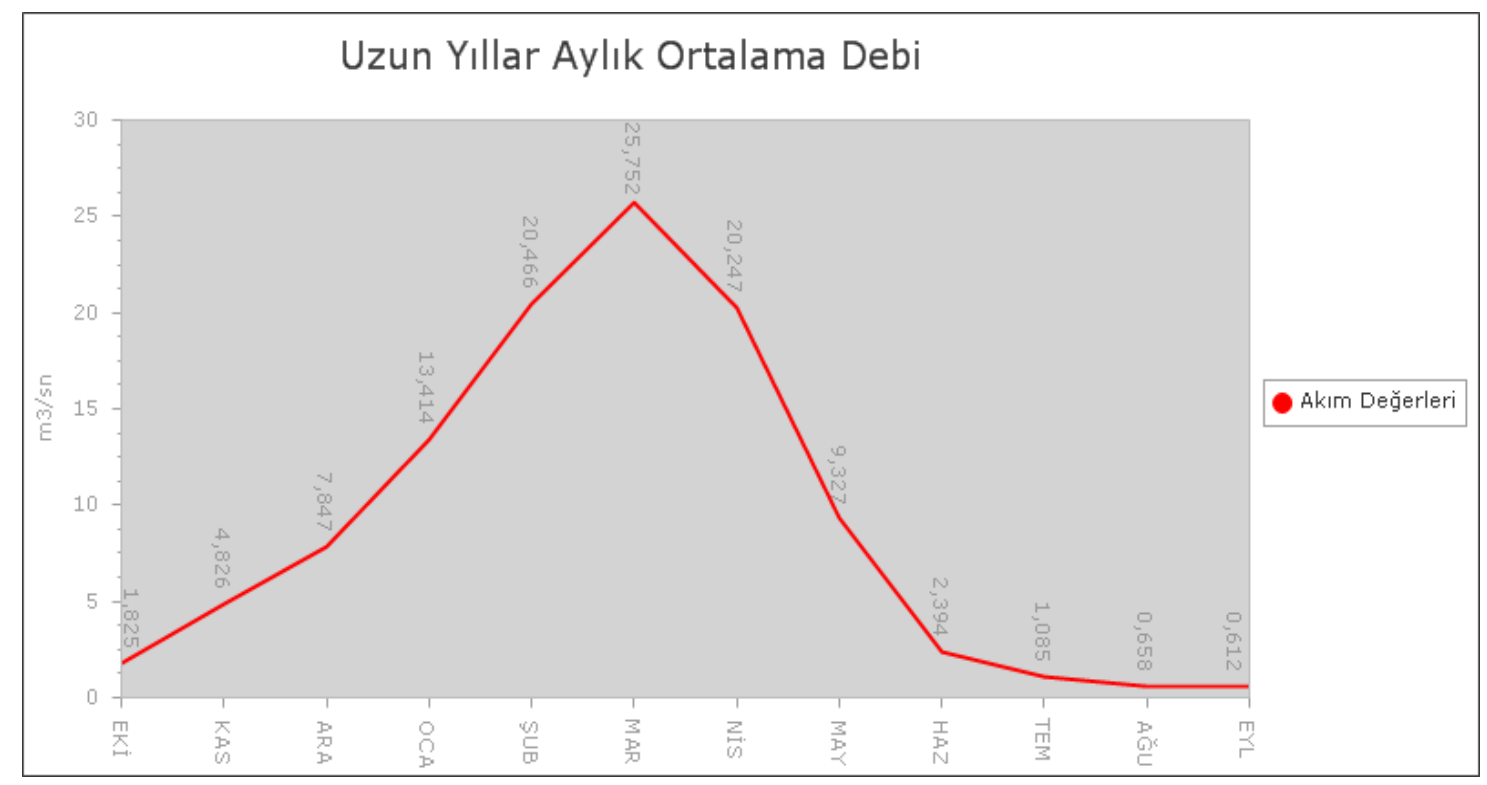

Grafik 1. Dicle Nehri Uzun Yıllar (1999-2019) Aylık Ortalama Debi Grafiği

Kaynak: Devlet Su İşleri- SVT Rasatlar Bilgi Bankası, 2020.

Çalışma alanındaki morfolojik çeşitlilik akarsu drenaj ağını da etkilemiştir. Tersiyerde meydana gelen kıta-kıta çarpışmasıyla yükselen araziyi dar ve derin bir boğazla yaran Kızılsu Çayı, burada 
eğim yönünde akarak konsekant özellik göstermektedir. Eğim yönünde akış gösteren Kızılsu Çayı'na katılan yan kollar ise dik ya da verev bir akış özelliği göstermekte ve subsekant bir şekilde Kızılsu Çayı'na bağlanmaktadır. Sunkar ve Tonbul'a (2008) göre tektonik hareketlere bağlı olarak yükselen dağlık alanların alçak eşik alanlarına antesedant gömülme görülebilir. Kuzeydoğu-Güneybatı istikametinde konsekant akan Kızılsu nehrinde de bu şekilde bir gömülme gerçekleşmiştir. Bu gömülme ile Kasrik Boğazı bir klüz şeklinde oluşmuştur. Başta konsekant bir şekilde akan Kızılsu Çayı yükselen araziyi yararak bu özelliğini yitirmiş ve inkonsekant bir akış şekli göstermiştir. Ancak nehre ulaşan yan kollar halen subsekant özelliklerini korumaktadırlar. Yüksek yerlerden Kızılsu vadisine inen yan kollar burada kafesli drenaj ağı oluşturmuşlardır. Özgen ve diğerlerine (2005) göre bu durum arazinin kıvrımlı ve kırıklı bir yapıya sahip olmasından kaynaklanmaktadır. Tektonik hareketler akarsuların kurulması ve gelişimleri boyunca yer ve yön değiştirmelerinde büyük bir etkiye sahiptir. Akarsuyun aşındırma özellikleri vadi şekli üzerinde etkili olduğu halde; vadi doğrultusu ve dolayısıyla akarsu sistemleri, tektonik yapının sonucu olarak bir yandan yeryüzü şekillerine diğer yandan da tektonik çizgilere bağlı bulunmaktadır. Senklinallere yerleşen akarsular belirli yerlerde antiklinalleri yararak bir sonraki senklinale yerleşmişlerdir. Yukarıda adı geçen Kızılsu Çayı'nın da kafesli drenaj sistemini oluşturması bu şekilde oluşmuştur. Antiklinalleri dik bir açı ile yararak boğaz (klüz) içinde akan Kızılsu Çayı çalışma alanında kafesli drenaj tipini meydana getirmektedir (Harita 4).

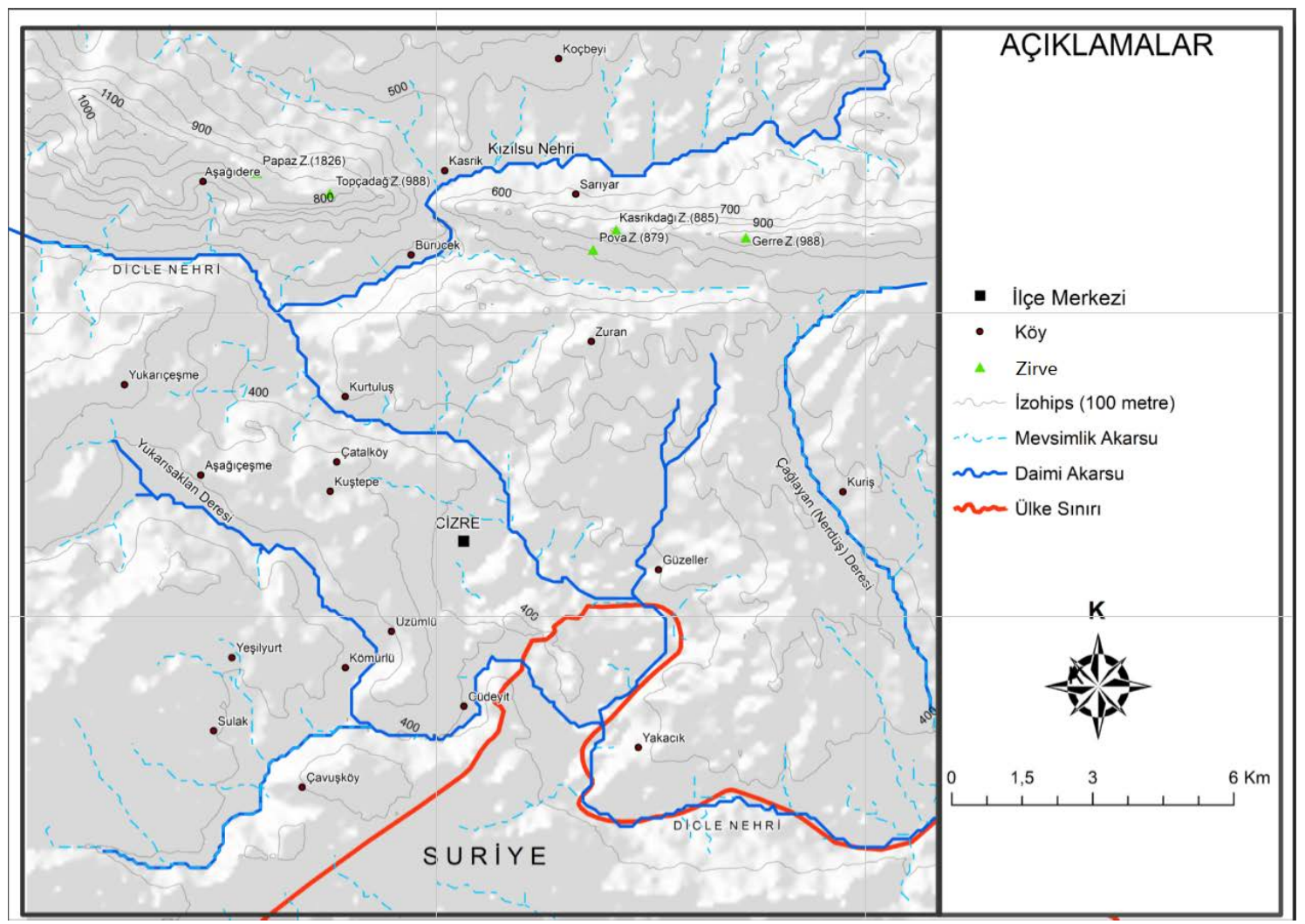

Harita 4: Çalışma alanının hidrografya haritası 


\section{İnceleme Alanının İklim Özellikleri ve Yer Şekillerine Etkisi}

Güneydoğu Anadolu Bölgesinde iklim koşulları, kontinental bir step ikliminin özelliklerini gösterir. Kış mevsiminde en düşük sıcaklık derecelerinin ve yağışların toplanmış olması, buna karşılık yaz mevsiminin çok sıcak ve kurak geçmesi, ana hatlarıyla bölgede Akdeniz tipi bir yağış rejiminin olduğunu gösterir (Sözer, 1984) (Grafik 2). Bu iklim tipi Akdeniz ikliminin kontinental bir şeklidir ve bölgede güney ve güneydoğuya doğru gidildikçe dereceli bir şekilde çöl iklimine geçer (Ardel, 1961; Çağlıyan ve Durmuş, 2010).

Cizre Meteoroloji Genel Müdürlüğünden alınan veriler (1970-2019) incelendiğinde çalışma alanının ikliminin Akdeniz iklimini yansıttığını söyleyebiliriz. Aylık ortalama sıcaklık değerlerine baktığımızda sıcaklığın yaz aylarında yükseldiğini ve kış aylarında da en düşük seviyeye ulaştı̆̆ını görüyoruz. Sıcaklık verilerine göre en yüksek sıcaklık ortalaması Temmuz ayında 34,3 $\mathrm{C}^{0}$ olarak ve en düşük sıcaklık ortalaması değeri de Ocak ayında 6,7 C0 olarak ölçülmüştür. Ayların sıcaklık ortalamasının yıllık değeri ise 19,9 Co 'dir. Buna göre kış sıcaklıklarının 0 Co 'nin altına düşmemesi kışların 1lık geçtiğini göstermektedir (Grafik 2).

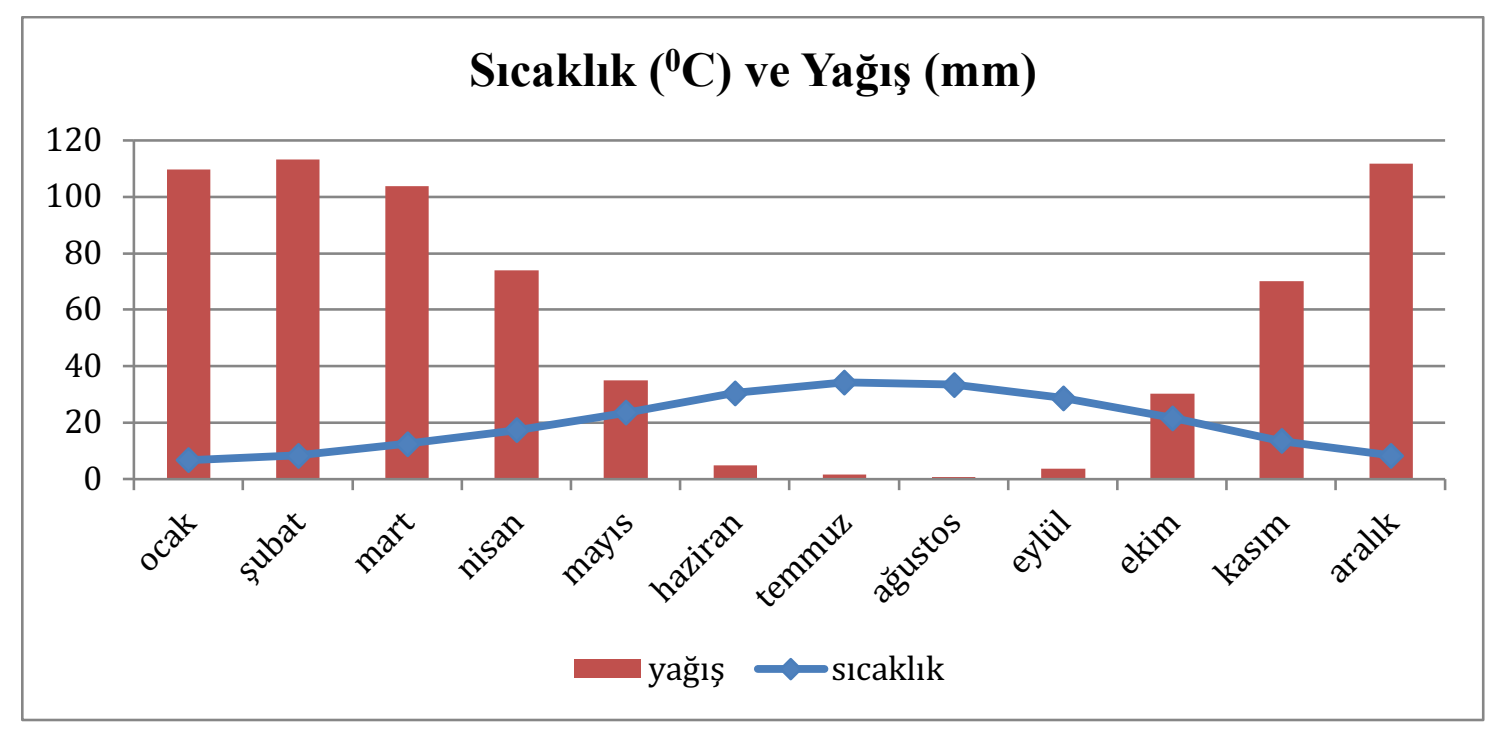

Grafik 2. Cizre İlçesine ait Sıcaklık ve Yağış Grafiği

Kaynak: Cizre Meteoroloji Müdürlüğü, 2020.

Dicle Nehri üzerinde sıcaklık faktörünün buharlaşmayı sağlama etkisi göz ardı edilemez ancak flüvyal sistemin gelişimi üzerinde yağış şekli ve miktarı daha fazla önem arz etmektedir. Yağışın en fazla kışın ve ilkbaharın başlarında etkili olması nehrin drenaj ağı üzerinde de etkili olmaktadır. Su miktarının bu dönemlerde artması akarsuyun aşındırma gücünü de etkilemektedir. Yağış rejiminin mevsimler arası değişiklik göstermesi akarsuyun rejiminin de değişmesine neden olmaktadır. Kızılsu Çayı'nın Dicle Nehri ile birleştiği kısımlardan, Cizre şehri içinden aktığı kısımlara kadar geniş tabanlı bir vadide akan akarsu burada örgülü drenaj ağ 1 göstermektedir. Su miktarının ve eğimin azalması ve biriktirme faaliyetlerinin artmasına bağlı olarak akarsu içinde kum adaları oluşmuştur.

\section{İnceleme Alanının Jeomorfolojik Özellikleri}

Çalışma alanında Geç-Orta Miyosen süresinde Bitlis kenet kuşağı boyunca Arabistan-Avrasya çarpışmasının etkileri birçok yerde görülmektedir. Bu çarpışma Türkiye bütününde, bölgenin 
tektoniğinde çok belirgin etkiler oluşturmuştur (Şengör ve Yılmaz, 1983). Sahada Tersiyer birimlerinin çoğunlukta olması da bu durumla alakalıdır. Yatay yapılı tabakaların çoğunlukta olduğu çalışma alanının Kasrik Boğazı çevresinde güney yönden Arap plakasının bindirmesinin etkisiyle tabakalar kuzeye doğru devrilmiş ve dikleşmiştir. Monoklinal yapılarda eğimin az olduğu yerlerde dikliği az olan kuestalar, eğimin artmasıyla dikleşir. Aşınmaya karşı dirençli olan tabakanın kalınlığı ve eğimi arttıkça kuesta eğimi de artar ve hogbek denilen dike yakın sırtlar halini alır (Atalay, 2016: 355). Kasrik boğazındaki yamaçlar hogbeklerin eğiminin artmasıyla tam dikleşmiştir. Neredeyse $90^{\circ}$ lik açılarla dikleşen bu yapılar aynı zamanda selektif aşınıma da uğramıştır (Foto 1-2). Daha sert ve dirençli olan kalker ve dolomitik taşlar kornişler oluştururken; kil, marn gibi yumuşak kayaçlar aşınmıştır. Yatay yapılarda çok nadir görülen bu dik yapılar vadinin her iki tarafında da uzanmaktadır. Tabakaların devrilip dikleşmesini sağlayan bindirmenin etkisiyle şaryaj olayı gerçekleşmiş ve eski tabakalar yeni tabakaların üzerini örtmüştür.

Güneydoğu Anadolu Bölgesinde önemli paleocoğrafik değişimlerin yaşanması Oligosen dönemi ve sonunda meydana gelen yoğun tektonizmanın etkisi sonucudur. Bu hareketlenmelere bağlı olarak bölgede çeşitli yapısal unsurlar gelişmiştir ve Orta Eosen sonrası regresyona neden olan tektonizma Eosen-Oligosen denizinin şeklini değiştirmiştir. Oligosen döneminde deniz seviyesinin gözle görülür bir şekilde alçalması Neotetis'in hızlı bir şekilde kapanması ve sı̆̆ denizel koşulların hakim olması sonucu gelişen yarı kapalı havzalarda karbonatlarla ardalanmalı evaporitler çökelmiştir (Güngör Yeşilova ve Helvacı, 2013). Kuzucuoğlu ve diğerlerine (2019) göre bu havzalar Geç Miyosen-Pliyosen gölleri ve sedimentleriyle kaplıydı. Çalışma alanında Kasrik Boğazı çevresinde Midyat grubu üyelerinin (kireçtaşı, dolomit, killi kireçtaşı vb.) yoğun olarak bulunması bu alanın geçmişte sı ğ denizel bir fasiyes ortamı olduğunu göstermektedir. Bu kapalı-yarı kapalı havzada istiflenen Midyat grubu karbonatları yatay tabakalar oluşturmuşlardır. Daha sonra bölgede meydana gelen tektonizmayla oluşan regresyon hareketi suların geri çekilmesini sağlamıştır. Karasal bir ortama dönüşen çalışma alanındaki yatay tabakalar güneyden gelen bindirmenin etkisiyle kıvrımlanmış ve dik yapılar oluşturmuşlardır (Foto 1-2).
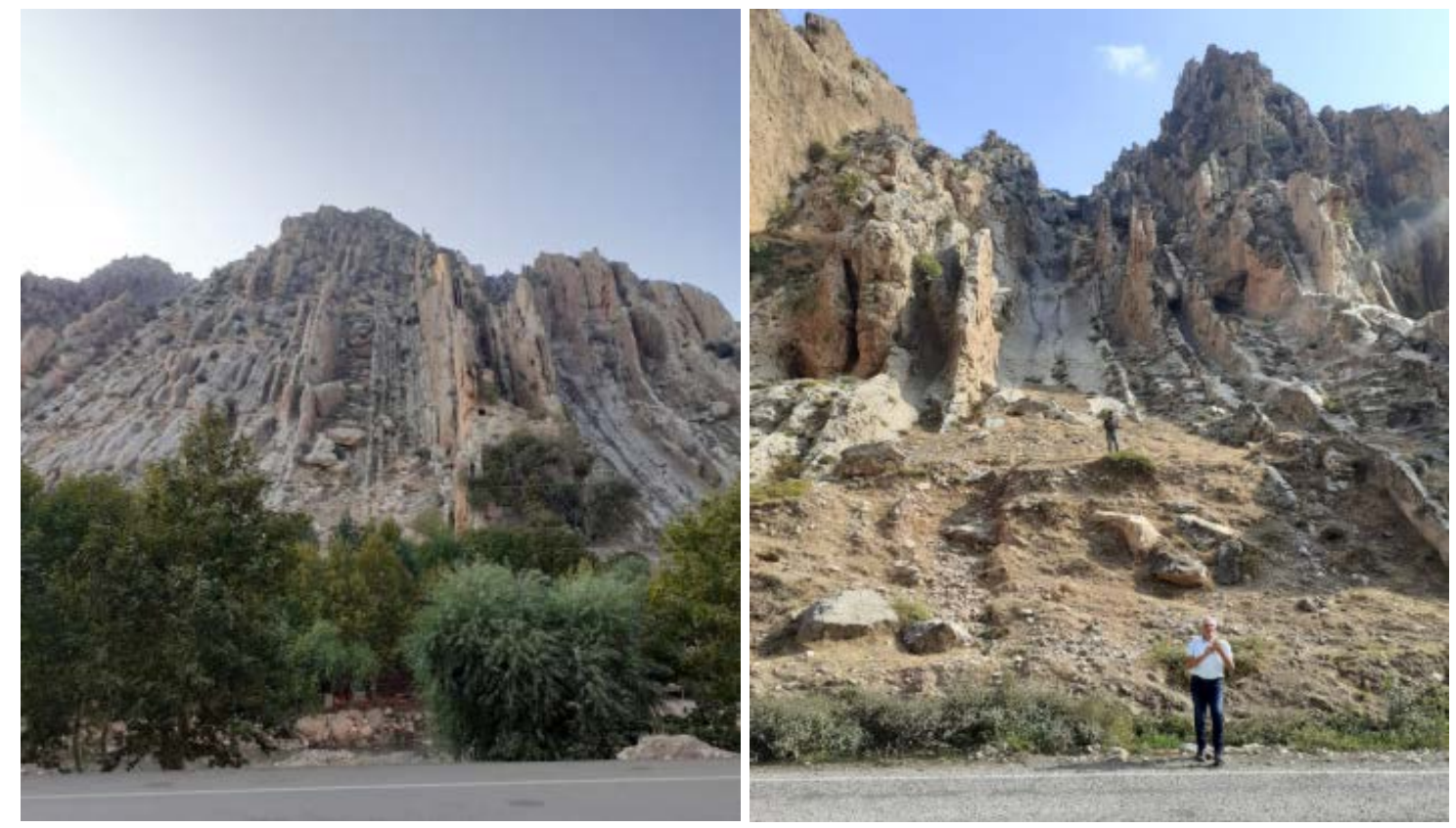

Foto 1-2. Kasrik Boğazı Çevresinde Gabar ve Cudi Dağlarının Eteklerinde Dikleşen Tabakalar (Kret). 
Anadolu'daki havzaların büyük bir bölümünün kara halini alması Pliyosen sonlarına karşılık gelir. Kara haline dönüşen yerlerde yeni akarsular kurulurken, daha önce kurulmuş olan akarsular var olan havzalarını parçalamışlardır. Bu devrenin en önemli özelliği, geriye doğru aşınım dalgasının ilerlemesi ile birbirine bitişik halde uzanan havzaların, kapma sonucunda birbirine bağlanmış ve bu şekilde de akarsu boylarının gittikçe uzamış olmasıdır (Yıldırım, 2004). Miyosen-Pliyosen dönemleri arasında geçen sürede kapalı bir havza olan Kızılsu Çayı geriye doğru aşınma yaparak Kasrik Boğazı'nı oluşturmuş ve kapma sonucu Dicle Nehri ile birleşmiştir.

Son buzul döneminde Anadolu'nun iç kısımlarında genel olarak buharlaşmanın azalmasından ve çevredeki yüksek yerlerden gelen kar ve buz sularının etkisiyle bazı kapalı havzalarımızda göller oluşurken, buradaki göllerin seviyesi yükselmiştir. Holosende ise Anadolu'da bir yandan buzulların erimesi diğer yandan da yağışların artması ile katastrofik karakterde seller ve su baskınları meydana gelmiştir. Buna ait en karakteristik örnek Mezopotamya'nın kuzeyinden başlayarak Basra Körfezi'ne kadar olan alanı kaplayan ve Nuh Tufanı olarak da bilinen selin oluşmasıdır. Dicle ve Fırat nehri kıyısında kalınlığı bazen 1 metreyi aşan yuvarlak kaya bloklarının eski toprak ve depolar üzerinde yer alması, insanın tahmin edemeyeceği kadostrofik bir taşkının olduğunu göstermektedir (Atalay, 2005). Zaman zaman taşan bu kapalı havza suları Kasrik Boğazının açıldığı yerdeki kalker tabakalarını aşındırıp zamanla boğazın açılmasını sağlamıştır. Yani bu kapalı havzanın dışarıya açılan göl ayağı çalışma alanındaki Kızılsu Çayı'dır ve Kasrik Boğazı da suların drene edildiği geçit noktasıdır (Foto 3).

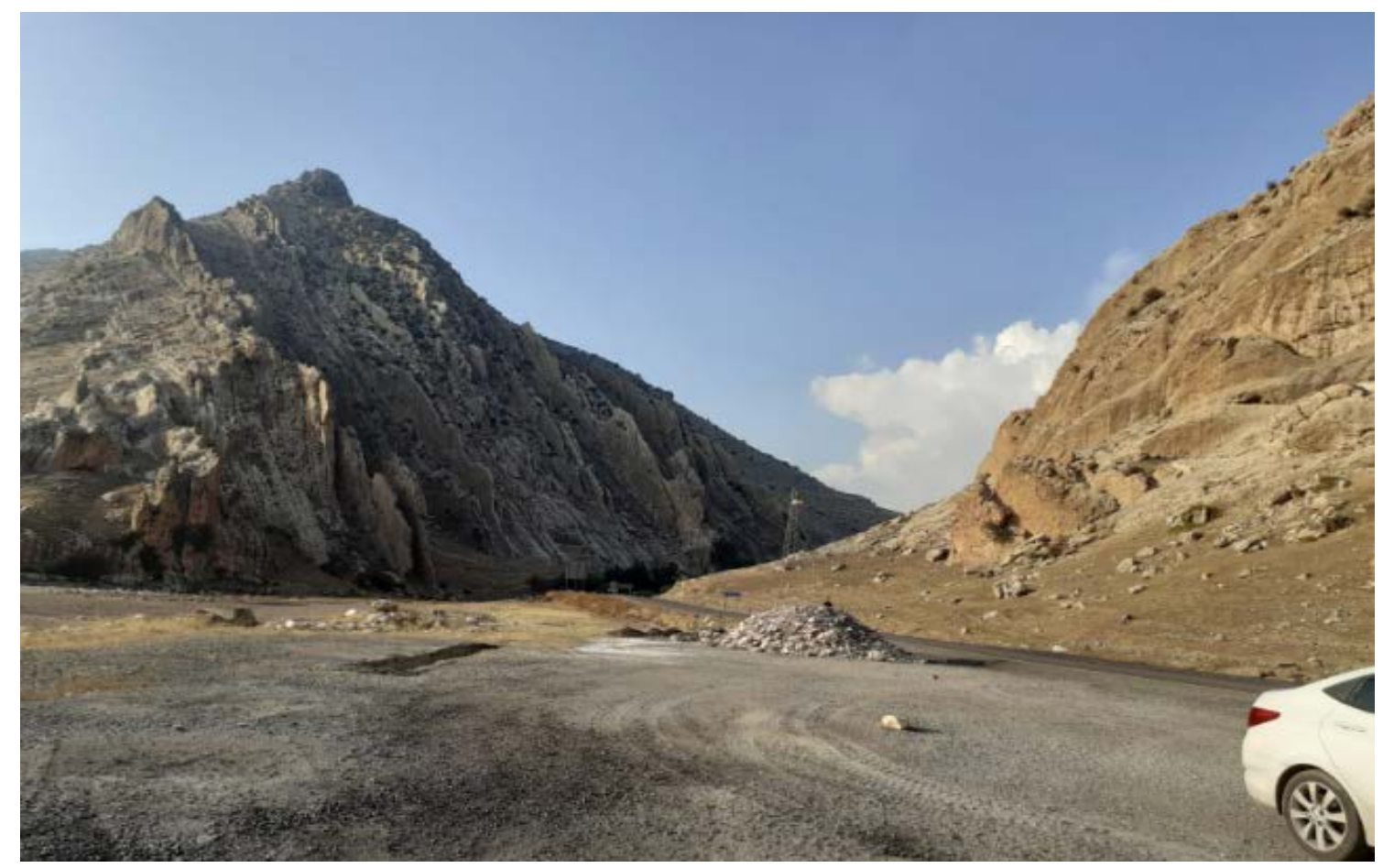

Foto 3. Kasrik Boğazı. Boğaz, Cudi ve Gabar Dağı Uzantılarının Birbirleriyle Birleştikleri Alandadir.

Deniz seviyesindeki çekilmeye bağlı olarak akarsular yataklarını derinleştirerek kıyıya yakın yüksek alanlarda yer yer dar ve derin vadiler açmıştır (Atalay, 2005). Boğaz açılırken taban seviyesinin değişmesi ve arazinin yükselmesi ile vadide taraçalar oluşmuştur. Antesedant yarma vadilerde gömülme aşamalarında oluşan kaya taraçaları Kasrik Boğazında da oluşmuştur. Ana 
kayayı yaran akarsu, oluşturduğu kaya taraçalarının üzerine de akarsu dolgusu bırakmıştır. Çoğunlukla topoğrafyada nadir olarak rastlanan kaya taraçaları bu alanda çok net görülmektedir (Foto 4-5). Taraçalar üstünde görülen alüvyon dolguları ise akarsuyun bir dönem yapmış olduğu biriktirmeyi gösterir.
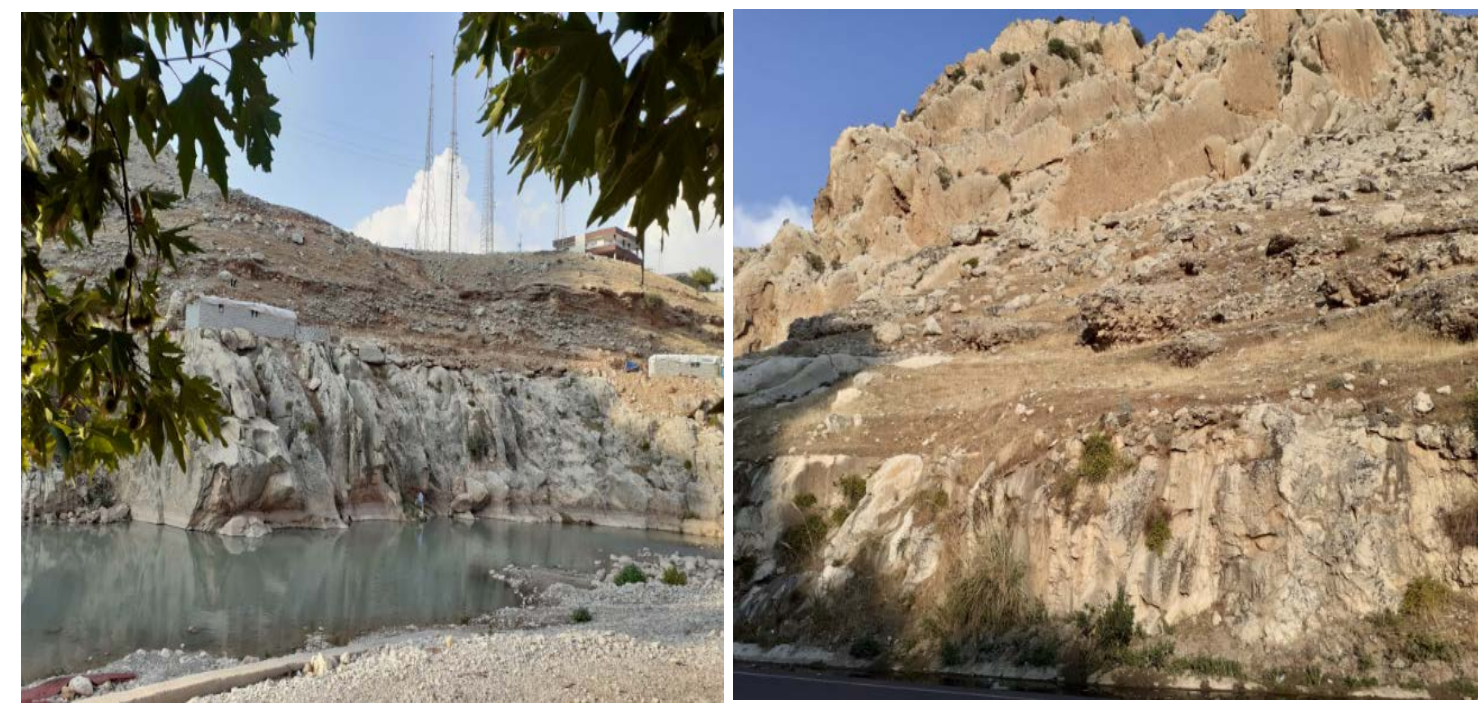

Foto 4-5. Kasrik'te Kızılsu Nehrinin Tektonik Hareketler Sonucu Oluşturduğu Kaya Taraçaları

Kasrik Boğazı ve Cizre arasında kalan alanda tespit edilen başlıca morfolojik birimler; dağlar, tepeler, platolar, aşınım düzlükleri, vadiler, bazalt sütunları, boğazlar, akarsu sekileri, karstik şekiller, birikinti yelpazeleri ve kum adalarıdır.

\section{Dağlar, Platolar ve Aşınım Düzlükleri}

Çeşitli jeomorfolojik evreler geçiren çalı̧̧ma alanında kıta-kıta çarpışması sonucunda oluşan Güneydoğu Toros Dağları silsilesine bağlı yüksek zirvelerden oluşan dağlar meydana gelmiştir. Sahanın en önemli dağı ve çalışma alanındaki en yüksek noktayı 2114 m yükselti ile Cudi Dağı oluşturmaktadır. Diğer önemli dağlık alan ise Gabar Dağı olup 1848 m ile zirve noktasına (Küpeli Tepe) ulaşmaktadır. Bu iki dağ sırası Kasrik Boğazının açıldığı yerde birbirlerine yaklaşırlar. Diğer önemli yükseltiler ise Pova Tepe ( 879 m), Kasrikdağı Tepe (885 m), Gerre Tepe (989 m), Topçadağı Tepe (988 m), Papaz Tepe (1826 m) dir (Harita 5).

Çalışma alanındaki bu iki dağ sırasının jeoloji ve jeomorfolojisi incelendiğinde kuzeye doğru bir bindirme kuşağının mevcut olduğu görülür. Bunun sonucunda meydana gelen devrilmeyle Orta-Üst Miyosen yaşlı Şelmo formasyonu Eosen yaşlı Midyat grubu tarafından uyumsuz bir şekilde örtülmüştür. Her iki tarafta da devrilip dikleşen yapılar Eosen yaşlı Midyat grubu üyelerinden oluşmaktadır. Genelde karbonatlardan oluşan Midyat grubu çalışma alanı sınırları içinde kalan bu iki dağ sırasında en fazla bulunan formasyon grubudur. Atalay (2016: 221)'a göre Oligosen sonlarına doğru geniş ölçüde aşınarak seviye alçalmasına uğrayan dağ kuşaklarımızın epirojenik hareketlerle tekrar yükselmeye uğraması, akarsu aşındırmasını hızlandırmıştır. Buna bağlı olarak dağ kuşaklarımız tekrar akarsularla yarılarak son derece engebeli bir görünüm almıştır. 
Midyat grubu üyelerinin çoğunlukta olduğu Gabar ve Cudi Dağlarında mağaralar ve lapyalar dikkat çekicidir. Kalkerin geniş alanlar kapladığı yurdumuzda, özellikle Toros Sıradağları karstik şekillerin en çok görüldüğü kuşaktır. (Doğu, Çiçek ve Gürgen, 1995). İnceleme alanı da bu kuşağın en doğusunda yer almaktadır.

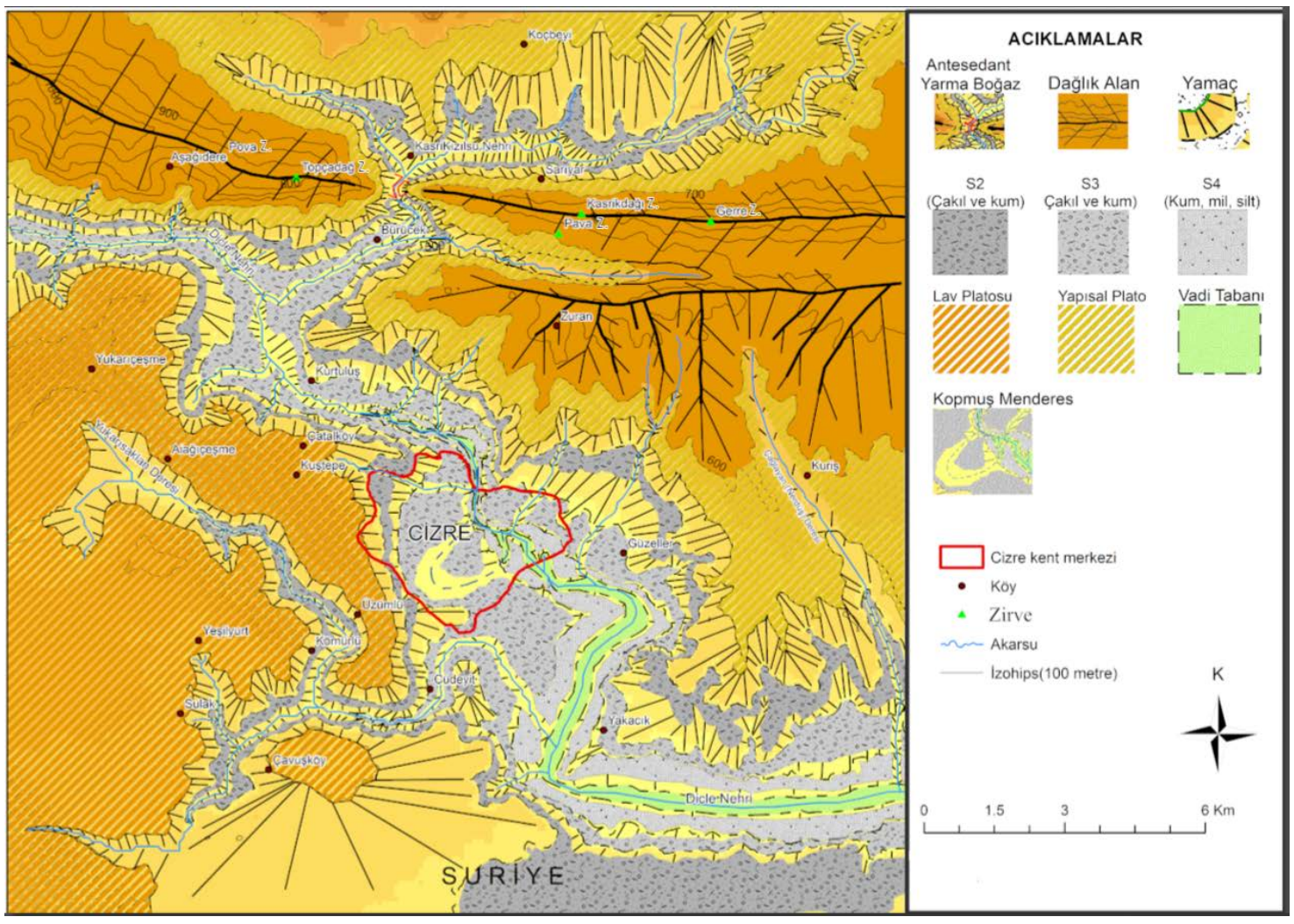

Harita 5. Çalışma Alanının Jeomorfoloji Haritası

Genç tektonik birimlerin (Miyosen, Pliyo-Kuvaterner, Kuvaterner) yer aldığı Cizre çevresinde çeşitli seviyelerdeki platolara karşılık gelen aşınım düzlükleri yer alır. Çalışma alanında D IV aşınım düzlükleri, eski alüvyonların ve hatta Şelmo formasyonunun olduğu yerlere tekabül eder. Çok geniş alanlar kaplayan ve yatay bir istiflenme gösteren Üst Miyosen yaşlı Şelmo formasyonu, kendisinden daha genç olan Kuvaterner dönemli bazaltlar tarafından yapısal (yatay) bir şekilde örtülmüştür. Bu yapısal şekiller komşu ülke Suriye sınırlarında da devam etmektedir. Biricik (1975)'in “İdil'i Cizre'ye bağlayan karayolunun bazı kesimlerinde bariz bir şekilde dikkati çeken bazalt platoları az çok masavari rölyefi meydana getirmiştir" diye ifade ettiği buradaki platolar karakteristik bir mesa oluşturmuştur. Çalışma alanının batı ve güneybatı tarafında görülen bazalt lavları yatay olarak uzanan tortul tabakaların üzerini örtmüştür ve bu alanda yaygın olarak yatay yapılı lav platolarına rastlanmaktadır (Harita 5).

Güneydoğu Anadolu Bölgesi volkanik reliefi, volkanizmanın son fazında çıkan bazalt lâvlarının egemen olduğu ve onların oluşturduğu geniş lâv platolarından oluşmuştur (Sür, 1994). Çalışma alanında da volkan coğrafyasına ait jeomorfolojik birimlerin İdil yakınlarındaki Alem Dağından püsküren ve geniş bir alana yayılan bazik ve akıcı lavlardan oluştuğu görülmektedir. Dicle nehrinin batı tarafında görülen bu lavlar Kuvaterner yaşlı olup Pliyo-Kuvaterner yaşlı Lahta formosyonu, Pleyistosen yaşlı eski alüvyonları ve bazı yerlerde de Miyosen yaşlı Şelmo formasyonuna ait yapısal düzlükleri örtmektedir. Ketin (1960) de Cizre yakınlarındaki bazalt lavların Pliyosen tabakaları bir örtü gibi kapladığını ve geniş alanlara yayıldığını ifade etmiştir. 
Canpolat'a (2005) göre İdil-Cizre arasındaki Kuvaterner bazaltları Arap Yarımadası kuzeyindeki tektonik hareketlerle ilişkilidir. Atıcı ve Türkecan'a (2017) göre çalışma alanında görülen volkanik alanların oluşumu bu düşünceyi destekler niteliktedir yani Arap platformu hareketiyle ilgilidir.
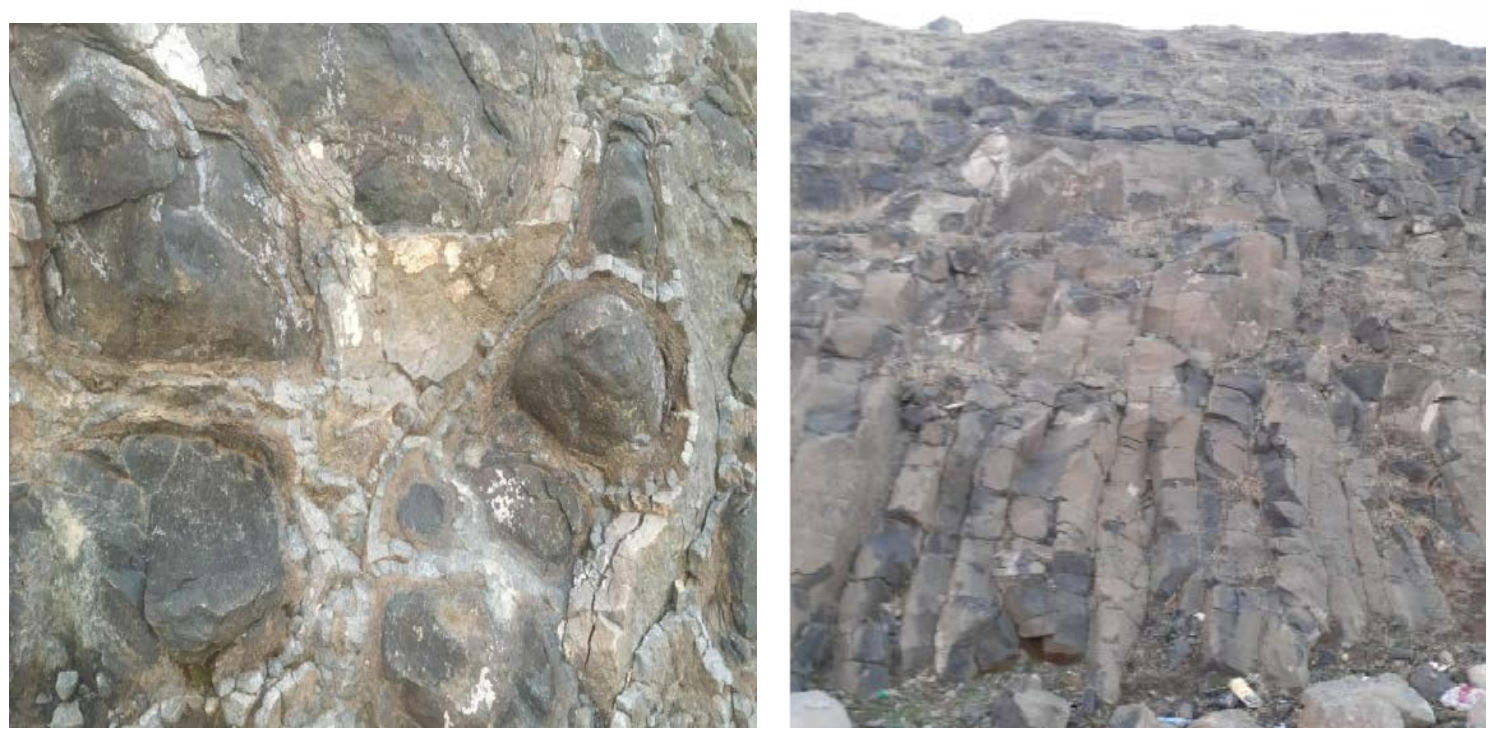

Foto 6-7. Cizre Seyir Tepesinde Yastık Lavlar, Eksfoliasyon Olayı ve Bazalt Sütunları

Bazaltların farklı renkte (siyah ve kahverengi) katmanlar oluşturmaları püskürmenin farklı fazlarda geliştiğini göstermektedir. İki bazalt tabakası arasında uzanan bazalt cürufu da başka bir tabakayı temsil etmekte ve bu durum fazlar arası farkı daha da belirginleştirmektedir. Patlama esnasındaki hava kabarcıklarının oluşturduğu delikli yapı cüruflarda net bir şekilde görülmektedir. Bazı yerlerde 1-2 metreyi bulan kalınlıkta oluşmuş bazalt toprağı da görülmektedir. İntrazonal toprak grubuna dahil olan bu topraklar horizonlaşma sürecini tamamlamamışlardır.

Çalışma alanındaki bu bazaltlar üzerinde oluşmuş bazı şekiller mevcuttur. Bunlardan biri bazalt sütunlarıdır. Dar bir alanda rastladığımız bazalt sütunları metrelerce uzunluğa sahiptirler ve kimi yerlerde yatay bir uzanış sergilemektedir. Bunun yanı sıra birbirinden net bir şekilde ayrılan ve yuvarlaklaşmış bazalt kayaçları mevcuttur (yastık lavlar). Bu kayaçlar üzerinde fiziksel ayrışmaya bağlı olarak gelişen eksfoliasyon olayının izleri görülmektedir (Foto 6-7).

\section{Akarsu Sekileri}

Dicle Nehri ve kolları tarafından açılmış olan vadiler üzerinde, vadi tabanından genelde 3 ile 125 m yükseklikteki seviyelerde gözlenen ve çalışma alanında sekilerle temsil edilen eski ve yeni alüvyonlar bulunmaktadır. Yarılma ve kazılma olayının oldukça şiddetli olması vadi tabanlarına göre bu kadar yüksek seviyelerde eski nehir taraçalarının oluşmasına neden olmuştur (Yıldırım ve Karadoğan, 2005).

Pleyistosen'in dört ana pluviyal-interpluviyal evrelerine uyan ve Pleyistosen'in genel iklim değişimlerine uygun düşen havzadaki taraçalar yukarıdan aşağıya doğru bu evrelere uygun olarak sıralanma gösterir. Pleyistosen'deki iklim değişikliklerinin etkisi ile Dicle Nehri'nnin Pleyistosen dönemindeki gömülme süreci kesintili olmuştur. Her duraklama döneminde yeni bir 
vadi tabanı oluşmuş, aşındırma faaliyetlerinin hızlandığı dönemlerde bu tabanlar yarılmış ve dört ana seki seviyesi oluşmuştur (Yıldırım ve Karadoğan, 2005). Karadoğan ve Kozbe'nin (2013) birlikte yürüttükleri çalışmalarında da Dicle Nehri taraçaları 4 basamak halinde sınıflandırılmıştır. Dicle Nehri, Pliyosen sonlarında havzanın dış drenaja bağlanması ile boşaltılmış geniş fluvio-laküstr düzlüklerinde menderesler yaparak akışını sürdürmüştür. Daha sonra Kuvaterner' de büyük iklim değişiklikleri dönemi başlamış ve Dicle Nehri vadisi ve çevresi bu jeoklimatik sürece bağlı olarak şekillenmiştir. Buzul dönemlerde genel taban seviyesi olan deniz yüzeyinin alçalmasına bağlı olarak akarsu yatağını derince kazmış, buzularası dönemlerdeki deniz seviyesi yükselmesine bağlı olarak ise alüvyal boğulma yaşanmış ve biriktirme dönemi başlamıştır. Bir sonraki buzul döneminde ise akarsu tekrar biriktirdiği depolara gömülerek eski vadi tabanı yamaçlarda seki olarak belirmiştir.

Çalışma alanında Dicle Nehri kıyısındaki seki sistemleri Pleyistosen'e ait (Erol, 2011 sinuflamasına göre) S1, S2, S3 ve Holosen'e ait S4 olarak adlandırılan sekilerdir. Bunların yüksekliği sırası ile, 100-125 m (S1), 50-70 m (S2), 10-30 m (S3) ve 3-5 m (S4) olarak belirlenmiştir. Çalışma alanında görülen tektonik hareketlerle alanın yükselmesi ve akarsuyun buraya gömülmesi sonucunda, sekiler alanın her yerinde aynı belirginliği koruyamamıştır (Harita 5).

\section{En Yüksek Sekiler (S1)}

En yüksekte (100-125 m) bulunan S1 sekisi genellikle bozulmuş durumdadır. En geniş seki seviyesini oluşturur. Nehrin her iki tarafında belirgin bir şekilde izlenememektedir. Değişik boyuttaki alüvyal malzemeler özellikle iri çakıllar seki deposunu oluşturmaktadır. Çalışma alanındaki eski alüvyonlardan oluşan Pliyo-Kuvaterner yaşlı Lahta formasyonu üzerinde oluşmuş seki sistemidir. Dicle Nehrinin batı tarafında uzanan bazalt lavları hem S1 seki seviyesini hem de Lahta formasyonunu örtmüştür. Yer yer mevsimlik akarsuların yataklarını aşındırmaları ile parçalanmış olarak izlenebilmektedir. Nehrin doğu tarafında ise belirginliğini koruyamayan bu seki basamağı akarsular tarafından çok fazla parçalanmış ve aşındırılmıştır.

\section{Orta Yükseklikteki Sekiler (S2-S3)}

Dicle Nehrinde beliren ikinci seviye S2 (50-70 m) sekisidir. Akarsu kolları tarafından yarılmış, parçalanmış ve bozulmuş bir durumdadır. Bu yüzden her yerde gözlenmez ve nehrin her iki tarafında da karşılıklılık ilkesini koruyamamışlardır. Karışık ve değişik boyuttaki malzemelerden oluşmuştur (çakıl, kum gibi.) Cizre şehir merkezine göre yüksekte kalmış bir seki seviyesi olmasına rağmen yine de yerleşme için kullanılmaktadır (Foto 8).

Çalışma alanında üçüncü seki seviyesi S3 (10-30 m) sekisidir ve Üst Pleyistosen yaşlıdır. Güneydoğu Anadolu'daki Dicle ve Fırat Nehirlerinin kenarlarındaki düzlük alanlarda daha önceki kadostrofik sel sırasında biriken kumlu ve çakıllı depolar üzerinde oluşan topraklardan taşınan bol miktardaki karbonat bileşikleri, altta bulunan toprakların üst katını kireçlemektedir. Toprakların alt katlarında rastlanan sert kireçli kat (kaliş), günümüzden önce toprağın üst kesiminden yıkanarak alt kesiminde biriken aşırı miktardaki karbonatlı maddelerdir (Atalay, 2005). Çalışma alanındaki S3 sekisinde iklim koşullarından dolayı çok sert ve pekişmiş çakıllardan oluşmuş, kaliş bağlamış depolar mevcuttur. Çok geniş alanda izlenen bu seki sisteminde Cizre şehir merkezi kurulmuştur. Yerleşme ve bağ bahçe tarımı için ayrılan topraklar çoğunluktadır (Foto 9). 


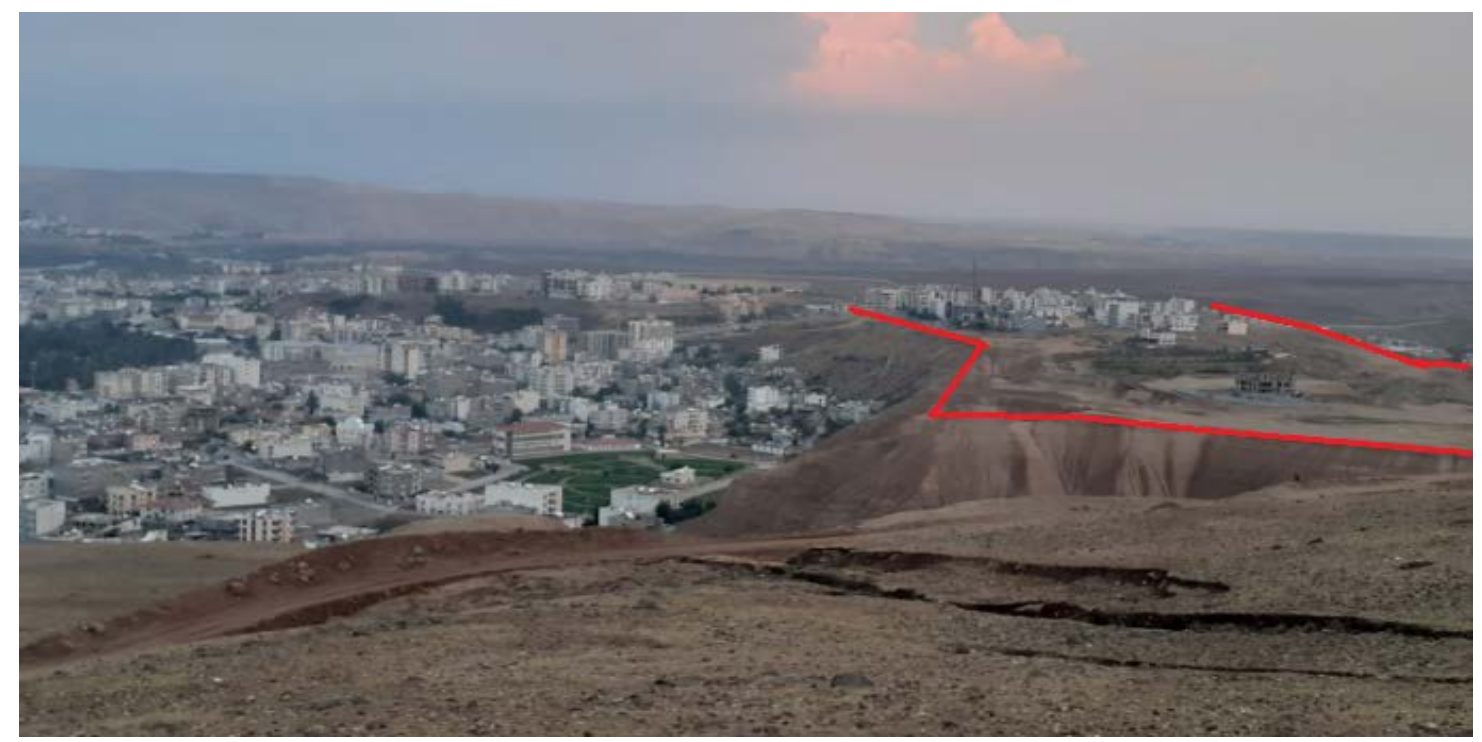

Foto 8. Cizre Seyir Tepesi Mevkinde Parçalanmış ve Yerleşime Açılmış S2 Sekisi

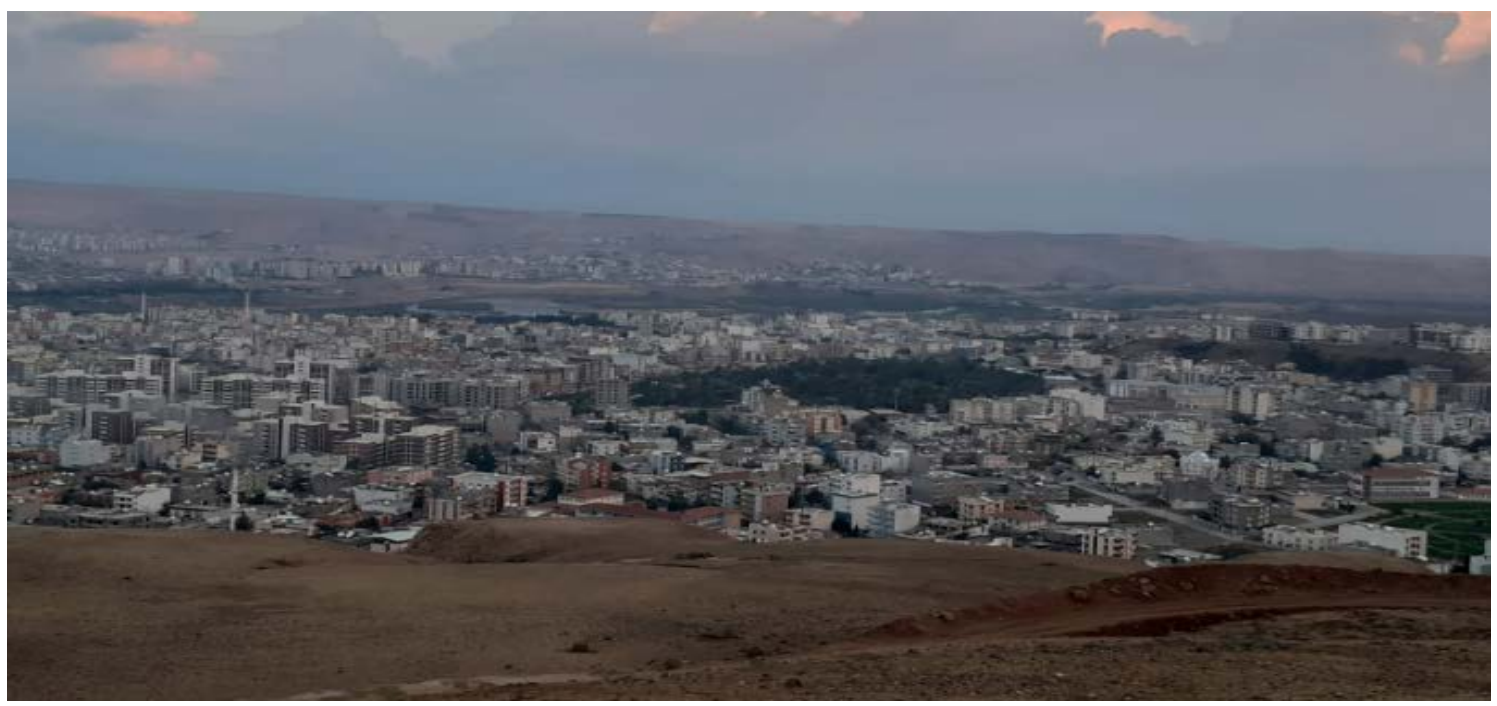

Foto 9. Dicle Nehrinin Her İki Tarafında da Cizre Şehir Merkezinin Kurulduğu S3 Sekisi

\section{Alçak Sekiler (S4)}

Sekiler içinde en genç olanı S4 (3-5 m) basamağıdır ve bu seki Dicle Nehrinin oluşturduğu en yeni alüvyonları kapsar. Dicle Nehri yatağındaki en alçak seviyeye denk düşmektedir. Değişik boyutlarda ve gevşek yapıda kum, silt ve mil malzemeleri sekiyi doldurmaktadır. Karadoğan ve Kozbe'ye (2013) göre depolardaki bu malzemeler, Holosen'de bir dönem havzanın alüvyal boğulma yaşadığını göstermektedir. Nehir içindeki kum adalarıyla aynı özellikleri gösteren bu seki sistemi üzerinde sazlıkların geniş yer kapladığı görülmektedir. 


\section{Vadiler, Vadi Tabanları ve Kum Adaları}

Çalışma alanındaki vadi tipleri ana akarsu olan Dicle Nehrine aittir. Bu alanda görülen vadi tiplerini şu şekilde sıralayabiliriz: Dicle Nehrinde geniş tabanlı vadi ve asimetrik vadi tipi, Kızılsu Çayında antesedant yarma vadi ve geniş tabanlı vadi tipi, mevsimlik akarsularda da basamaklı kertik vadi ve menderes vadi tipi.

Dicle Nehri çalışma alanında geniş tabanll, dar ve derin olmayan bir vadide akış gösterip eğimin azaldığı yerlerde akarsu içinde kum ve çakıl adaları biriktirmiştir. Bu adalar Holosen yaşlı irili ufaklı malzemelerin (kum, kil, çakıl vb) birikmesiyle meydana gelmiştir. Kasrik Boğazını geçtikten sonra geniş bir alanda akmaya başlayan Kızılsu Çayı de Dicle Nehriyle birleştiği yerlerde bu adaları oluşturmuştur. Akımın yükseldiği ilkbahar ve kış aylarında bu adalar suyun altında kalmaktadır (Foto 10).

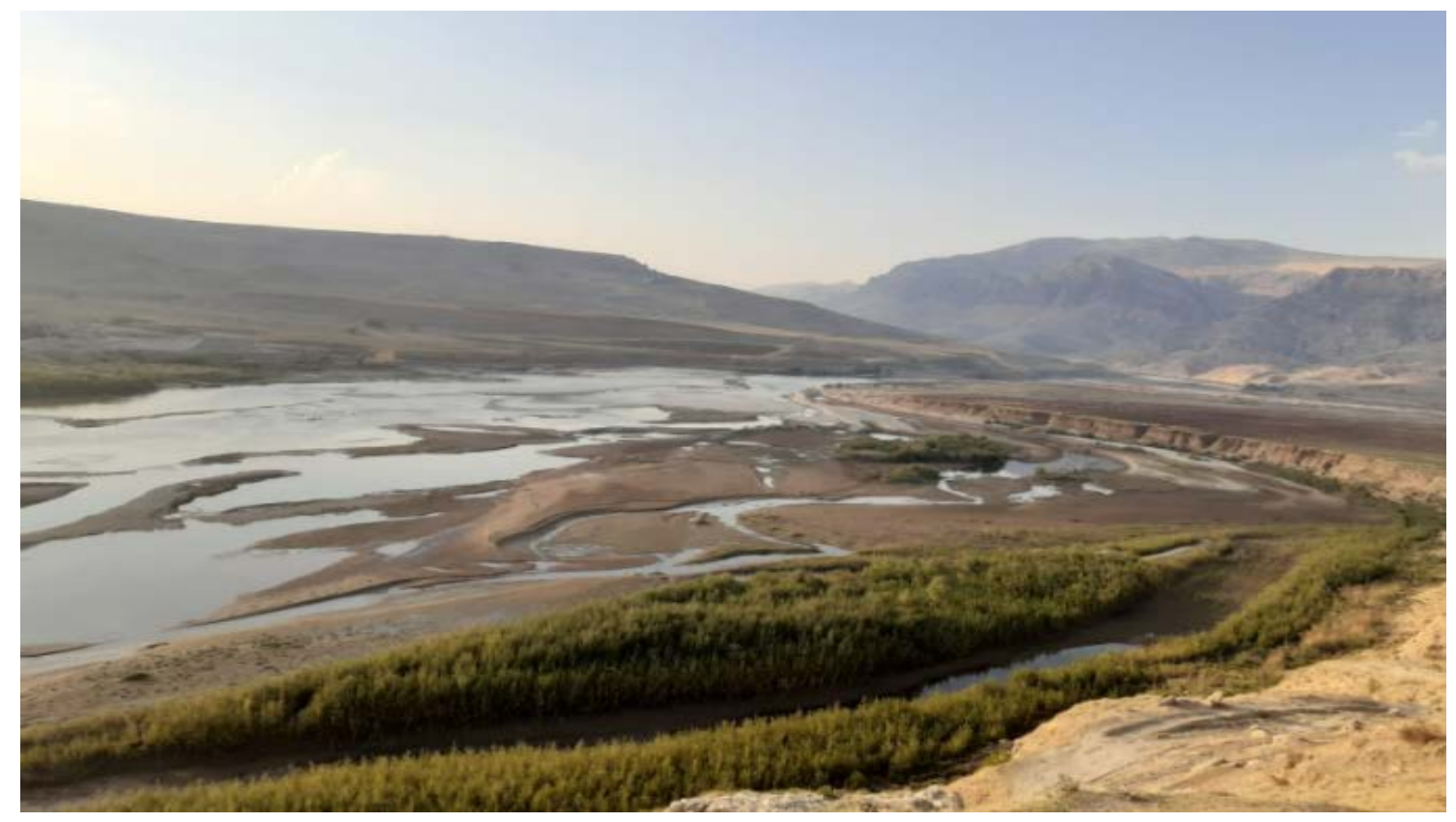

Foto 10: Dicle Nehrinin Kızılsu Nehri ile Birleştikten Sonra Gösterdiği Örgülü Akış, Kum Adaları ve Çarpak-Yığınak Şekilleri

Neojen döneminde kapalı bir havza olan Kasrik Boğazı çevresinde uzun bir dönem tortullanma meydana gelmiştir. Bu havzada biriken tortullar (havza depoları) daha sonra arazinin yükselmesi ve suların çekilmesiyle açığa çıkmış ve boğaz açılırken bu tortullar çarpılmıştır. Bu tortullar arasına gömülen Kızılsu Çayı geriye doğru aşınma yapmış ve Kasrik Boğazını yararak Dicle nehri ile birleşmiştir. Bindirme kuşağı boyunca yükselen bu arazide açılan Kasrik Boğazı antesedant yarma vadi özelliği göstermektedir. Çünkü Tersiyerde meydana gelen kıta-kıta çarpışması sonrası bölgenin yükselmesi gibi genç tektonik hareketlere bağlı olarak yükselen sahanın kıvrımlı yapılarını, Kızılsu Çayı adeta bir testere gibi yarmıştır. Dağ kuşaklarında yükselme olmadan önce eğim yönünde (konsekant) akış gösteren Kızılsu Çayı, dağların yükselmesiyle yatağını kazmaya ve dağları yarmaya başlamıştır. Oluşturduğu antesedant yarma vadiyle inkonsekant bir akışa sahip olmuştur. Derin bir şekilde boğazı yardıktan sonra geniş tabanlı bir vadiye bürünüp Dicle Nehri ile birleşmektedir. 


\section{SONUÇ ve ÖNERILER}

Kasrik Boğazı ve Cizre arasında kalan çalışma alanı Türkiye'nin, özellikle Güneydoğu Anadolu kenar kıvrım kuşağının oluşumunda önemli olan jeolojik-tektonik ve jeomorfolojik olayların çok belirgin izlerini taşıyan oldukça zengin bir morfolojiye sahiptir.

Tersiyer-Kuvaterner birimlerin çoğunlukta olduğu çalışma alanı tektonizma ve jeomorfolojik olayların etkisiyle şekillenmiş ve şekillenmeye de devam etmektedir. Miyosen'de sığ bir denizle kaplı olan bölge, Tetis denizinin çekilmesiyle karasal-gölsel bir kapalı havza olmuştur. Bu havzada biriken tortullar kıta-kıta çarpışmasıyla yükselmiş ve bölgedeki dağ kuşaklarının oluşumunu sağlamıştır. Pleistosen'deki iklim değişimleriyle kapalı olan bu havza Kızılsu Çayı'nın açtığı Kasrik Boğazıyla dış drenaja açılmış ve Dicle Nehri ile birleşmiştir. Antesedant yarma vadi özelliği gösteren bu boğazın her iki yamacında da yatay yapılı tabakaların bindirme fayı etkisiyle oluşturduğu dik yapılar (kret) görülmektedir. Kıta çarpışması öncesinde eğim yönünde akış gösteren Kızılsu Çayı, boğazın açıldığı yerde antiklinalleri yararak inkonsekant bir özellik kazanmıştır. Nehre bağlanan yan kolların bağlanma doğrultuları göz önünde tutularak kafesli drenaj ağının görüldüğü söylenebilir. Tüm bu olaylar sonucu şekillenen alan önemli turizm potansiyeli barındırmaktadır.

Flüvyal jeomorfolojinin de önemli bir şekillendirici unsur olduğu çalışma alanında Dicle Nehri vadisi ve taraça sistemleri de incelenen başka bir konudur. Dicle Nehrinin bölgede oluşturduğu 4 taraça seviyesi (S1, 100-125 m; S2, 50-70 m; S3, 10-30; S4, 3-5 m) Kuvaterner'deki iklim değişimlerinin bir yansımasıdır. Cizre şehir merkezinin de kurulmuş olduğu (S3) bu taraça sistemleri farklı alanlarda kullanılmaktadırlar (yerleşme, tarım, hayvancılık gibi). Çalışma alanının bu kesiminde yatay olarak uzanış gösteren tabakalar yapısal birimleri oluşturmaktadır. İdil yakınlarında bulunan Alem Dağı kaynaklı bazaltların üzerini örttüğü lav platoları yüksek düzlükler oluşturmuştur.

Bu çalışmada ele alınan Cizre ve çevresi, şehrin sağlıklı ve planlı bir şekilde kalkınması ve şehirsel dokunun sürdürülebilirliği açısından fiziki coğrafya ile beşeri hayatın uyumunun ortaya konulduğu güzel bir örnektir. Tüm bu coğrafi olayların sonucunda bölgede meydana gelen değişimler ve oluşan şekiller görülmeye ve araştırılmaya değerdir. Özellikle sahadaki volkanik unsurlar araştırılmaya değer bir konudur.

\section{KAYNAKLAR}

Ardel, A. (1961). Güneydoğu Anadolu'da Coğrafi Müşahedeler, Türk Coğrafya Dergisi, İstanbul, $0(21), 140-148$.

Atalay, İ. (2005). Kuvaterner'deki İklim Değişmelerinin Türkiye Doğal Ortamı Üzerindeki Etkileri, İstanbul Teknik Üniversitesi Avrasya Yer Bilimleri Enstitüsü. Türkiye Kuvaterner Sempozyumu Turqua V. 121-128.

Atalay, İ. (2016). Uygulamalı Jeomorfoloji, İzmir: Meta Basım Matbaacılık Hizmetleri.

Atıcı, G. ve Türkecan, A. (2017). Anadolu'nun Volkanları, Doğal Kaynaklar ve Ekoloji Bülteni, (22), $1-18$.

Bedirhanoğlu Yıldız, H. (2013). Yukarı Dicle Havzasında Su Kalitesinin Zenginleşme Faktörü Kullanlarak Zamana ve Mekana Bağ̆ı Değişiminin İncelenmesi, Yüksek Lisans Tezi, Hacettepe Üniversitesi, Ankara.

Biricik, A. S. (1975). Mardin ve Mücavir Mıntıkasının Strüktür ve Jeomorfolojisi, Türk Coğrafya Dergisi, (26), 26-65. 
Canpolat, E. (2005). Karacadăg (Diyarbakır) Volkanı Jeomorfolojisi, (Yüksek Lisans Tezi), İstanbul Üniversitesi, İstanbul.

Coşkun, N., Ayman, İ., Yumruk, Ş., ve Aşkar, İ. T. (2019). 2017 Yılı Şırnak İli Merkez, Güçlükonak, Uludere ve Beytüşşebap İlçeleri Yüzey Araştırması, 36. Araştırma Sonuçları Toplantısı, (3), 175-194.

Çağlıyan, A. ve Durmuş, E. (2010). Diyarbakır Havzası ve Yakın Çevresinde Küçükbaş Hayvancilık, Firat Üniversitesi Sosyal Bilimler Dergisi, 20 (2), 29-56.

Doğu, A.F., Çiçek, İ., ve Gürgen, G. (1995). Orta Toroslar (Seydişehir-Gülnar) Karstlaşma Tipleri, Türkiye Coğrafyası Araştırma ve Uygulama Merkezi Dergisi, (3), 130-139.

Erol, O. (2011). Genel Klimatoloji. (9.bask1). Çantay Kitabevi.

Ergün, Z. ve Gürbüz, A. (2012). Fırat ve Dicle Nehirleri'nin Sediman Taşınım Miktarları Üzerinde Jeomorfolojik, İklimsel ve Antropojenik Etkiler, 65.Türkiye Jeoloji Kurultayı, 574-587.

Güneysu, A. C. (1989). Karst Araştırmalarında Jeomorfolojinin Rolü, İstanbul Üniversitesi Deniz Bilimleri ve Coğrafya Enstitüsü Bülteni, (6), 137-142.

Güngör Yeşilova, P. ve Helvacl, C. (2013). Germik Formasyonu Oligosen Evaporitlerinin (Kurtalan, GB Siirt) Diyajenezi ve Paleocoğrafik Gelişimi, Hacettepe Üniversitesi Yerbilimleri Uygulama ve Araştırma Merkezi Bülteni, Yerbilimleri, 34 (1), 1-22.

http://svtbilgi.dsi.gov.tr/ [Erişim tarihi: 12.04.2020]

Karadoğan, S. (2018). Garzan Havzasında Jeomorfolojik Peyzaj ve Etkileri, Researcher: Social Science Studies, 6 (2), 237-271.

Karadoğan, S. ve Coşkun, A. (2018). Zerzevan Kalesi ve Çevresinde Jeomorfoloji Araştırmaları. İ. Özcoşar, A. Karakaş, M. Öztürk ve Z. Polat. (Editörler). Diyarbakır: Mekan, Toplum, Ekonomi. Birinci Basım. İstanbul: Ensar Neşriyat, 1- 16.

Karadoğan, S. ve Kozbe, G. (2013). Yukarı Dicle Havzasının (Batman-Bismil Arası) Jeomorfolojik Özellikleri ve Arkeolojik Yerleşme/Buluntu Yerlerinin Dönemler Boyunca Mekan Etkileşimleri", Ege Üniversitesi Yayınları Edebiyat Fakültesi, (181), 539-564. (Profesör Doktor İlhan Kayan'a Armağan). Bornova, İzmir.

Ketin, İ. (1960). Türkiye'de Magmatik Faaliyet, İstanbul Teknik Üniversitesi Maden Fakültesi, İstanbul. 1-33.

Kuzucuoğlu, C., Çiner, A. and Kazanc1, N. (2019). The Geomorphological Regions of Turkey, Landscapes and Landforms of Turkey, Springer Nature Switzerland AG. 41-178.

Meteoroloji Genel Müdürlüğü. (2020). Cizre Meteoroloji Genel Müdürlüğü.

MTA, (2007). Cizre İlçesinin 1/100.000'lik Jeoloji Haritası, Maden Tetkik ve Arama Genel Müdürlüğü, Jeoloji Etüdleri Dairesi, Ankara.

Özgen, N., Tonbul, S. ve Karadoğan, S. (2005). Siirt Çevresinde Kıvrımlı Yapı Elemanları, Jeomorfolojik Özellikleri ve Gelişimi. 1-16.

Siler, M. ve Şengün, M.T. (2016). İdil (Şırnak) Kuzeyinin Jeomorfolojik Özellikleri, Türk Coğrafya Dergisi, (66), 11-17.

Sözer, A.N., (1984). Güneydoğu Anadolu'nun Doğal Çevre Şartlarına Coğrafi Bir Bakış, Ege Coğrafya Dergisi, (2), 8-30. İzmir. 
Sunkar, M. ve Karataş, Z. (2014). Kahta Çayı Aşağı Havzası'nın (Adıyaman) Jeomorfolojik Özellikleri, Türk Coğrafya Dergisi, (63), 23-42.

Sunkar, M. ve Tonbul, S. (2008). Batman Şehrinde Yer Seçiminin Jeomorfolojik Özellikler ve Doğal Risk Açısından Değerlendirilmesi, Ulusal Jeomorfoloji Sempozyumu (Prof. Dr. M. ARDOS Anısina), 103-114.

Sür, A. Ö. (1994). Türkiye'de Volkanizma ve Volkanik Yerşekilleri, Ankara Üniversitesi, Türkiye Coğrafyası Araştırma ve Uygulama Merkezi Dergisi, (3), 28- 52.

Şengör, A.M.C. ve Yılmaz, Y. (1983). Türkiye'de Tetis'in Evrimi: Levha Tektoniği Açısından Bir Yaklaşım, Türkiye Jeoloji Kurumu Yer Bilimleri Özel Dizisi, (1). Ankara.

Yıldırım, A. (2004). Raman-Gercüş Antiklinalleri Yöresinde Dicle Nehrinin Hidrografik Özellikleri ve Kapma Olayları, Marmara Coğrafya Dergisi, (10), 117- 128. İstanbul.

Yıldırım, A. ve Karadoğan, S. (2005). Raman-Gercüş Antiklinalleri Arasında Dicle Vadisinin Jeomorfolojisi, Ulusal Coğrafya Kongresi, (Prof. Dr. İsmail Yalçınlar anısına), 421-429. İstanbul.

Yıldırım, A. ve Karadoğan, S. (2010). Güneydoğu Anadolu'nun Jeo-Tektoniği ve Depremselliği, Güneydoğu Anadolu Bölgesi Belediyeler Birliği Araştırmaları, (2). Anka Matbaacılık, Çantay yayıncilık.

Zeybek, M., Ahıska, S., ve Yıldız, S. (2016). Dicle Nehri (Türkiye) Oligochaeta (Annelida) Faunasının Taksonomik Açıdan Belirlenmesine Yönelik Bir Ön Araştırma, Ege Journal of Fisheries and Aquatic Sciences, 33(1), 47-53. 